\title{
Microphysical Properties and Radar Polarimetric Features within a Warm Front
}

\author{
S. CH. KEPPAS \\ Centre for Atmospheric Sciences, School of Earth and Environmental Sciences, \\ University of Manchester, Manchester, United Kingdom \\ J. CROSIER \\ Centre for Atmospheric Sciences, School of Earth and Environmental Sciences, and National Centre for \\ Atmospheric Science, University of Manchester, Manchester, United Kingdom \\ T. W. CHOUlarton AND K. N. BOWER \\ Centre for Atmospheric Sciences, School of Earth and Environmental Sciences, University of \\ Manchester, Manchester, United Kingdom
}

(Manuscript received 20 February 2018, in final form 4 May 2018)

\begin{abstract}
On 21 January 2009, the warm front of an extensive low pressure system affected U.K. weather. In this work, macroscopic and microphysical characteristics of this warm front are investigated using in situ (optical array probes, temperatures sensors, and radiosondes) and S-band polarimetric radar data from the Aerosol Properties, Processes and Influences on the Earth's Climate-Clouds project. The warm front was associated with a warm conveyor belt, a zone of wind speeds of up to $26 \mathrm{~m} \mathrm{~s}^{-1}$, which played a key role in the formation of extensive mixed-phase cloud mass by ascending significant liquid water (LWC; $\sim 0.22 \mathrm{~g} \mathrm{~m}^{-3}$ ) at a level $\sim 3 \mathrm{~km}$ and creating an ideal environment at temperatures $\sim-5^{\circ} \mathrm{C}$ for ice multiplication. Then, "generating cells," which formed in the unstable and sheared layer above the warm conveyor belt, influenced the structure of the stratiform cloud layer, dividing it into two types of elongated and slanted ice fall streaks: one depicted by large $Z_{\mathrm{DR}}$ values and the other by large $Z_{\mathrm{H}}$ values. The different polarimetric characteristics of these ice fall streaks reveal their different microphysical properties, such as the ice habit, concentration, and size. We investigate their evolution, which was affected by the warm conveyor belt, and their impact on the surface precipitation.
\end{abstract}

\section{Introduction}

Extratropical cyclones have been extensively studied, as such systems often demonstrate complicated cloud structures, providing an ideal environment for microphysical studies (e.g., Matejka et al. 1980; Chen and Cotton 1988; Forbes and Clark 2003; Stark et al. 2013; Crosier et al. 2014; Lloyd et al. 2014; Dearden et al. 2016). The typical structure of cyclones consists of a cold, a warm, and an occluded front, which usually affect the United Kingdom with strong winds and heavy rainfall (e.g., Browning 2004; Lavers et al. 2011). The fronts are associated with warm and cold conveyor belts, which circulate air masses with different traits. Warm conveyor belts (WCBs), which usually originate in surface maritime areas, convey humid

Corresponding author: Jonathan Crosier, jonathan.crosier@ manchester.ac.uk air, making a substantial contribution to the cloud structure and surface precipitation (Harrold 1973; Browning 1986; Eckhardt et al. 2004; Pfahl et al. 2014). Although all types of fronts have particularities and mechanisms that need further investigation, studying warm fronts is important, as they account for the majority of the precipitation associated with extratropical cyclones (Keyser 1986; Wakimoto and Bosart 2001).

Dual-polarization radars have been a valuable tool for revealing cloud microphysical properties, providing details about ice crystal habits, dimension, shape, orientation, and phase of hydrometeors. Various studies have been conducted on linking polarimetric radar variable thresholds with specific hydrometeor types (e.g., Herzegh and Jameson 1992; Straka et al. 2000; Hogan et al. 2002; Kennedy and Rutledge 2011; Moisseev et al. 2015; Schrom and Kumjian 2016) and determining polarimetric signatures, which can provide insight into cloud microphysical 
processes (e.g., Hall et al. 1984; Illingworth et al. 1987; Hubbert et al. 1998; Smith et al. 1999; Ryzhkov et al. 2005; Kumjian and Ryzhkov 2008; Kumjian 2013). Comparing and linking in situ cloud measurements with radar data can improve and validate the interpretation of the remote sensing data and, therefore, the understanding of cloud microphysics, including the role of primary (Koop et al. 2000; Vali et al. 2015) and secondary ice production (Hobbs and Farber 1972; Hallett and Mossop 1974; Mossop and Hallett 1974; Pruppacher and Schlamp 1975; Vardiman 1978; Knight 1979; Choularton et al. 1980) and embedded convection mechanisms. Embedded convective turrets, which appear as cells with horizontal and vertical extent of up to 6 and $2 \mathrm{~km}$, respectively, are referred to as "generating cells" (GCs) and have been documented several times in the literature (Wexler and Atlas 1959; Houze et al. 1976; Hobbs and Locatelli 1978; Herzegh and Hobbs 1981; Kumjian et al. 2014; Plummer et al. 2014; Rosenow et al. 2014; Plummer et al. 2015; Oue et al. 2015; Rauber et al. 2015; Keeler et al. 2016a,b, 2017; and many others). Discussing some of the latest studies, Plummer et al. $(2014,2015)$ used in situ (2D-C and 2D-P) together with a Doppler radar (reflectivity factor and Doppler velocity) in order to investigate the microphysics of GCs and the fall streaks originated in them. In addition, Rosenow et al. (2014) used an airborne W-band radar to quantify the magnitude of the vertical velocities in GCs, while Keeler et al. (2016a,b, 2017) used models to simulate GCs and examine their origin, their forcing, and their relationship to vertical wind shear, ambient thermal instability, and cloud-top radiative forcing. A mechanism that commonly triggers GCs is Kelvin-Helmholtz instability, which happens when velocity shear occurs in a single continuous fluid (Browning et al. 1973; Hogan et al. 2002). GCs usually present updrafts of $<3 \mathrm{~m} \mathrm{~s}^{-1}$, and they are often associated with descending trails of ice crystals and snow, which are commonly referred to as "ice fall streaks." Ice fall streaks, the shape of which is affected by the vertical wind shear, originate in and form from generating cells and play an important role in the production of precipitation (e.g., Marshall 1953; Langleben 1956; Douglas et al. 1957; Wexler and Atlas 1959; Bader et al. 1987; Kumjian et al. 2014; Rosenow et al. 2014; Oue et al. 2015).

In this study, we use high-resolution collocated in situ and active remote sensing observations obtained from dualpolarization data to provide (i) a detailed picture of the microphysical structure of a warm front and (ii) analysis of the structure, the origin, and the effects of the ice fall streaks, which are frequently embedded within warm fronts.

\section{Methodology}

The data used in this study were obtained during the NERC-funded Aerosol Properties, Processes and Influences on the Earth's Climate (APPRAISE)-Clouds project, which took place in the United Kingdom during 2007-10. This cloud project aimed to provide a comprehensive investigation of mixed-phase clouds influencing U.K. weather systems and the impact of aerosols on the microphysical properties and development of such clouds (Crosier et al. 2011; Crawford et al. 2012).

\section{a. The in situ datasets}

The U.K. Facility for Airborne Atmospheric Measurements (FAAM) Bae-146 aircraft was used to collect in situ measurements of cloud properties during APPRAISE-Clouds. In particular, on 21 January 2009 during flight B424, the aircraft extensively sampled clouds associated with a warm front over southern England, performing a series of straight and level runs, profiles, and sawtooth profiles over the period 1500 2000 UTC. The sampling occurred along a radial of $255^{\circ}$ within $\sim 100-\mathrm{km}$ range from the Chilbolton Facility for Atmospheric and Radio Research (CFARR; located at $51.15^{\circ} \mathrm{N}, 1.44^{\circ} \mathrm{W}$ ) to allow direct comparison with radar scans along the same azimuth. Hourly radiosondes were also launched from the Chilbolton ground site between 0700 and 1800 UTC.

The FAAM Bae-146 aircraft was equipped with microphysical probes, which provide measurements of a wide range of hydrometeors, as described in Crosier et al. (2014). Key instrumentation used in this work included a Mie-scattering cloud droplet probe (CDP), measuring number and size $(\sim 3$ and $50 \mu \mathrm{m})$ of cloud droplets (Lance et al. 2010); two-dimensional stereo (2D-S) and cloud imaging probe-100 (CIP-100) optical array probes (OAPs), providing shadow imagery of particles with size 10-1280 and 100-6200 $\mu \mathrm{m}$ (Knollenberg 1970; Lawson et al. 2006), respectively; and a Rosemount probe to measure the ambient deiced temperature. It should be highlighted that the 2D-S probe provides better resolution $(10 \mu \mathrm{m})$ and wider size range $(10-1280 \mu \mathrm{m})$, compared to its previous version, 2D-C $(25 \mu \mathrm{m} ; 25-800 \mu \mathrm{m})$. Particle phase was estimated based on a shape analysis of images obtained with the 2D-S and CIP-100, while ice number concentration and diameter (from the diagonal of the bounding box around the recorded particle image) was estimated according to Crosier et al. (2011, 2014). An interarrival time threshold was used to filter OAP images to remove artifacts associated with shattering of large particles on the probes according to Field et al. (2006).

To estimate bulk ice-phase parameters, including mean diameter and concentration, the 2D-S and CIP100 datasets were merged, and measurements in overlapping sizes were averaged. Ice water content (IWC) was calculated from merged 2D-S and CIP-100 particle size distributions using estimates of particle mass from 
Heymsfield et al. (2007). Significant uncertainties $(\sim 50 \%$ for IWC) can arise because of the diversity in OAP image processing options. Liquid water content (LWC) was estimated from the CDP particle size distribution.

\section{b. The remote sensing datasets}

During the flight, the Chilbolton Advanced Meteorological Radar (CAMRa) performed range-height indicator (RHI) scans along the $255^{\circ}$ (WSW) radial every $\sim 90$ s to obtain near-collocated radar and in situ measurements. The CAMRa is a dual-polarization Doppler radar that operates at $3 \mathrm{GHz}$ with a steerable $25-\mathrm{m}$ dish, resulting in a narrow $0.28^{\circ}$ beam (Goddard et al. 1994). Additionally, the zenith-pointing, dual-polarization, $35-\mathrm{GHz}$ Copernicus radar, which is located within $50 \mathrm{~m}$ of the CAMRa, was operating throughout the day. In contrast to low-frequency radars, which are applied for precipitation observations (Kollias et al. 2007; Fukao and Hamazu 2013), high-frequency radars are significantly affected by attenuation due to precipitation (Godard 1970). The cross-sectional ratio between large and small particles at such high frequencies is smaller, compared to longer wavelengths, so it is an ideal tool for monitoring clouds and fog. All references to data from the $35-\mathrm{GHz}$ vertical-pointing radar will be indicated by the subscript " 35 "; otherwise, the data being discussed are from the $3-\mathrm{GHz}$ radar.

In this study, we use radar variables, such as reflectivity factor $Z_{\mathrm{H}}$, Doppler velocity $V_{\mathrm{RAD}}$, and differential reflectivity $Z_{\mathrm{DR}}$, to examine cloud dynamical and microphysical structures; $Z_{\mathrm{H}}$ can be affected by the size and concentration of the hydrometeors (Doviak et al. 1979). Doppler velocity provides an estimate of the motion of hydrometeors, which can indirectly be used to infer, depending on the mode of operation, information on wind fields or the fall speeds of hydrometeors (Browning and Wexler 1968). Finally, $Z_{\mathrm{DR}}$ is the ratio between the radar reflectivities at horizontal and vertical polarizations, expressed in logarithmic scale induced by hydrometeors within the radar beam (Seliga and Bringi 1976), and can be used to provide details about their shape, orientation, and phase. We highlight that $Z_{\mathrm{DR}}$ data coming from elevations $<0.2^{\circ}$ have been excluded due to vertical beam blockage (Ryzhkov et al. 2002; Giangrande and Ryzhkov 2005).

\section{The synoptic condition}

On 21 January 2009, a deep, low pressure system in the northwest Atlantic Ocean moved eastward and developed (Fig. 1a). This system generated multiple frontal boundaries, which approached the United Kingdom
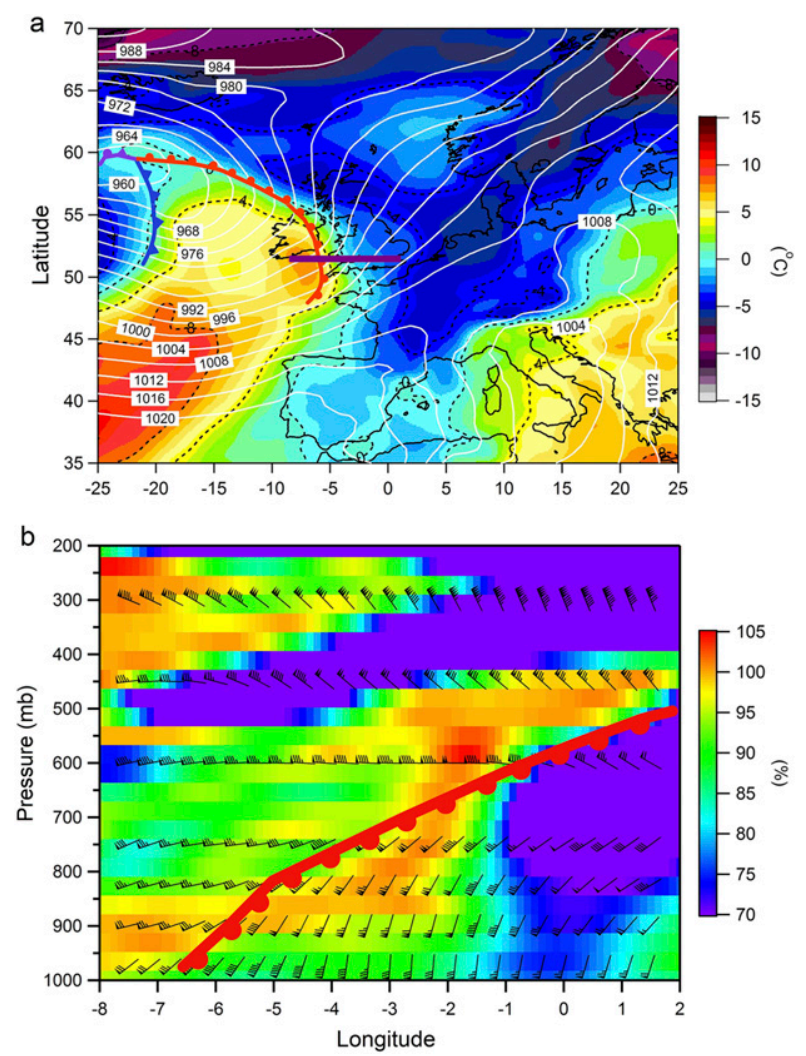

FIG. 1. ERA-Interim $\left(0.125^{\circ}\right.$ resolution $)$ at 1800 UTC 21 Jan 2009. (a) Temperature $\left({ }^{\circ} \mathrm{C}\right)$ on the $850-\mathrm{mb}(1 \mathrm{mb}=1 \mathrm{hPa})$ pressure level (color shading and dashed contours) and mean sea level pressure (mb) (white contours). Surface fronts have been plotted in accordance with Met Office analysis charts. (b) Vertical section of relative humidity (color shading) and wind speed/direction (standard wind barbs) across the investigated warm front at 1800 UTC [purple line in (a)]. Warm front position is highlighted by the red line according to wind and potential temperature fields.

from the west. The Bae-146 research flight sampled the warm front as it passed across the south of England. This warm front was observed to be associated with a WCB, which originated in the warm sector of the system (Fig. 1). Figures 1a and 1b show that the WCB transported humid and warm air over the colder air found over the U.K. mainland. In Fig. 1b, the WCB becomes perceptible through the zone of enhanced relative humidity and strong south-southwest to west winds (up to $23 \mathrm{~m} \mathrm{~s}^{-1}$ ), which reached a level of $\sim 450 \mathrm{mb}$ ( $\sim 6-\mathrm{km}$ height).

\section{A macroscopic description of the cloud features}

A brief description of the entire in situ and radar dataset is provided in order to understand the general cloud structures in the lower/midtroposphere during the passage of the warm front shown in Fig. 1a. 

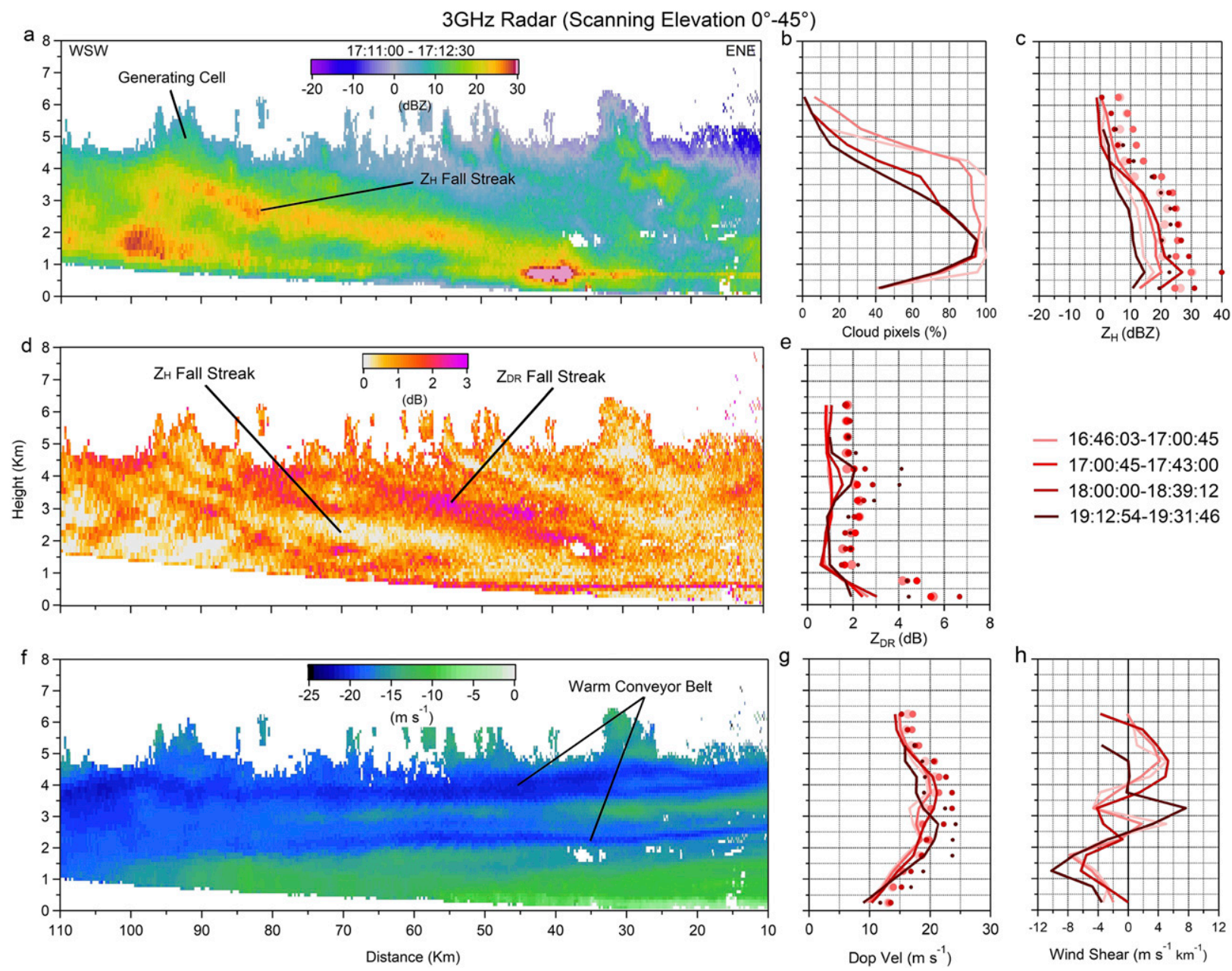

FIG. 2. The 3-GHz radar RHI scans of (a) $Z_{\mathrm{H}}(\mathrm{dBZ})$, (d) $Z_{\mathrm{DR}}(\mathrm{dB})$, and (f) unfolded Doppler velocity $\left(\mathrm{m} \mathrm{s}^{-1}\right.$ ) at 1711:00-1712:30 UTC (negative values indicate flow toward the radar). (b) Percentage of cloudy pixels $\left(Z_{\mathrm{H}}\right.$ dataset was used) with height. (c),(e),(g), (h) Graphs show average (solid lines) and 95th percentiles (dots) of $Z_{\mathrm{H}}, Z_{\mathrm{DR}}$, Doppler velocity, and vertical wind shear produced from Doppler velocity, which were calculated from the $3-\mathrm{GHz}$ radar dataset for $30 \leq$ range $\leq 90 \mathrm{~km}$ and $0 \leq$ altitude $\leq 8 \mathrm{~km}$ for the most representative scans during each time period shown in the legend. Different colors indicate different time periods for (b),(c), (e),(g),(h).

The spatial structure of the frontal cloud obtained from CAMRa at 1712 UTC is depicted in Fig. 2. Several features, which can be seen in Fig. 2, were consistently observed throughout the frontal passage and will now be discussed in turn. First, we observed GCs presented as protruded cloud tops, which demonstrated high- $Z_{\mathrm{H}} /$ low$Z_{\mathrm{DR}}$ cores $(>10 \mathrm{~dB} Z / \sim 0 \mathrm{~dB})$ and low- $Z_{\mathrm{H}} /$ high- $Z_{\mathrm{DR}}$ $(<10 \mathrm{~dB} Z />1 \mathrm{~dB})$ boundaries (Figs. 2a,d) (e.g., Bader et al. 1987; Kumjian et al. 2014; Oue et al. 2015). A $Z_{\mathrm{H}}$ ice fall streak (e.g., Bader et al. 1987; Kumjian et al. 2014; Oue et al. 2015) is represented as a long (tens of $\mathrm{km}$ ) and narrow $(\sim 1 \mathrm{~km})$ slant (angle of $\left.3^{\circ}-7^{\circ}\right)$ zone of high $Z_{\mathrm{H}}$ (enhanced by $10-15 \mathrm{~dB} Z$ relative to the surroundings) (Fig. $2 \mathrm{a}$ ) and $\sim 0$-dB $Z_{\mathrm{DR}}$ (Fig. 2d) containing mostly rimed/aggregated crystals (Fig. $5 ; 2<$ altitude $<3.5 \mathrm{~km}$ ). Then, $Z_{\mathrm{DR}}$ fall streaks (e.g., Bader et al. 1987; Kumjian et al. 2014; Oue et al. 2015), typically located above a $Z_{\mathrm{H}}$ fall streak, exhibited a zone of high $Z_{\mathrm{DR}}(>1 \mathrm{~dB})$ (Fig. 2d) and low $Z_{\mathrm{H}}$ $(<10 \mathrm{~dB} Z)$ (Fig. 2a) values consistent with the presence of pristine ice crystals (Fig. $5 ; 3<$ altitude $<5 \mathrm{~km}$ ). Although Fig. 2 does not show an ideal example of GC, it highlights the connection between a GC and a $Z_{\mathrm{H}} / Z_{\mathrm{DR}}$ fall streak (see details in section $5 b$ ). Finally, Fig. $2 \mathrm{f}$ presents two banded layers of enhanced Doppler velocity associated with the so-called warm conveyor belt, an airstream that appears in RHIs between 2 and $4 \mathrm{~km}$, which transports humid and warm air aloft.

An overview of the major temporal changes in the cloud structure can be seen in the vertical-pointing 35-GHz radar data (Fig. 3). It should be noted that 

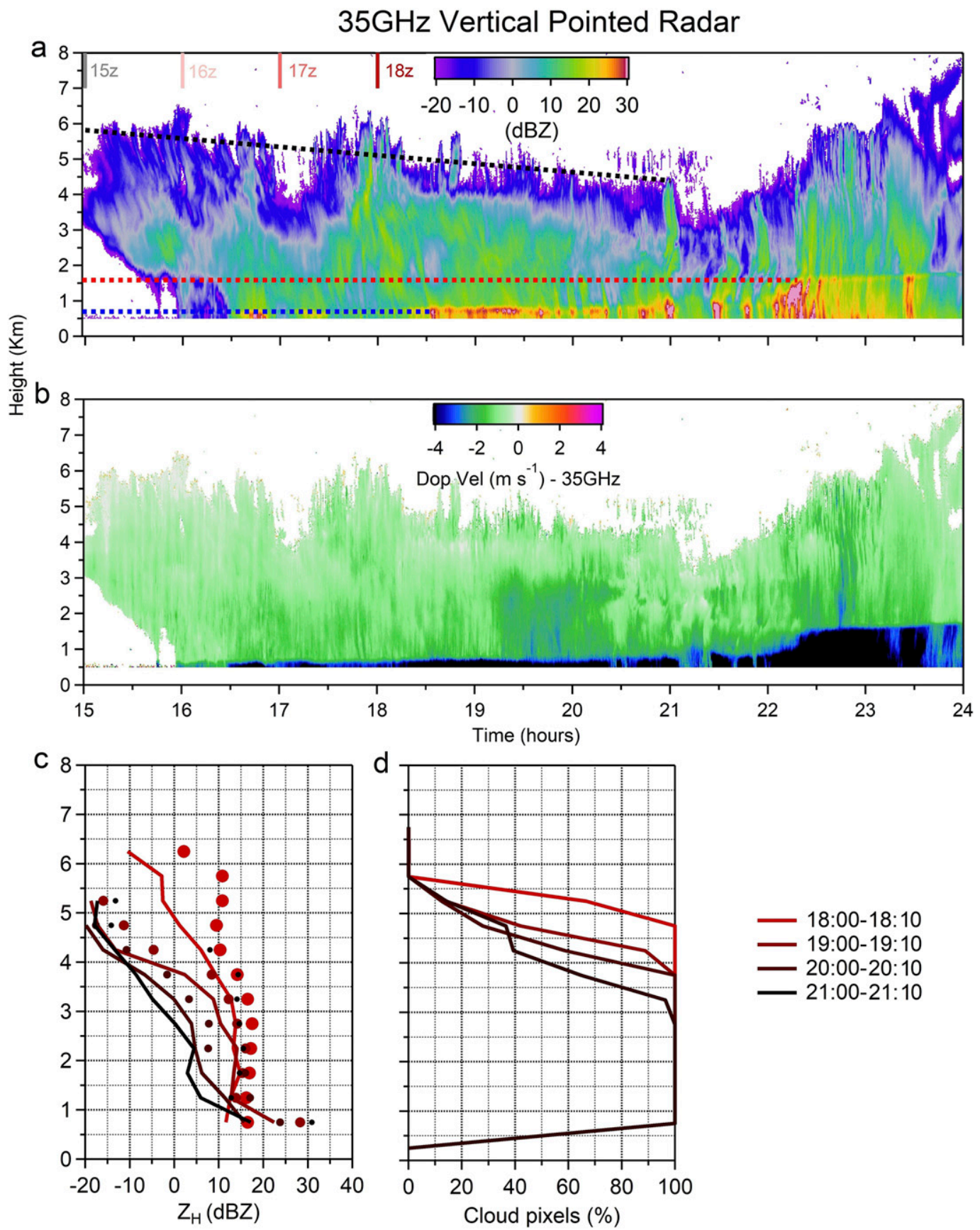

FIG. 3. (a) $Z_{\mathrm{H}}(\mathrm{dBZ})$ and (b) Doppler velocity $\left(\mathrm{m} \mathrm{s}^{-1}\right)$ evolution with time as captured by the $35-\mathrm{GHz}$ radar. In (a), the ML height is highlighted by the blue (time $<2100$ UTC), the green $(2100<$ time $<2215$ UTC), and the red (time $<2215$ UTC) dashed lines. The black dashed line shows the linear fitting of the cloud-top heights between 1500 and 2100 UTC. The colored lines on the left corner indicate the time that radiosondes of Fig. 4 were launched, compared to the time color scale of (a). In (b), negative Doppler velocity indicates flow toward the radar. (c) Average (solid lines) and 95th percentiles (dots) of $Z_{\mathrm{H}}$ as calculated from 35-GHz radar data. (d) As in Fig. 2b, but for the 35-GHz radar dataset. (c),(d) Calculated from the first $10 \mathrm{~min}$ of data of each hour.

clouds located at horizontal distances between 30 - and 90-km range in the $3-\mathrm{GHz}$ radar scans are estimated to overpass the 35-GHz radar 25-75 min later (based on a typical wind speed of $\sim 20 \mathrm{~m} \mathrm{~s}^{-1}$ along the radar profile).
Although comparisons between these two radar datasets will not be fully correlated, as the system may change during transit, it reveals useful general trends of the system over time. 
In Fig. 3a, we can see a change in the height of the freezing level or "melting layer" (ML). The ML appears as a bright band in the reflectivity field, the $Z_{\mathrm{H}}$ signal of which increases depending on the type and concentration of the hydrometeors that enter this region (Fabry and Zawadzki 1995). The $Z_{\mathrm{H}}$ increases within the ML due to the change of the phase and shape of melting hydrometeors, which also affects $Z_{\mathrm{DR}}$ (e.g., Stewart et al. 1984; Zrnić et al. 1993; Szyrmer and Zawadzki 1999; Giangrande et al. 2008). Before the passage of the warm front $(<2215$ UTC), the ML was observed at $\sim 0.7-1 \mathrm{~km}\left(Z_{\mathrm{H}_{-} 35}\right.$ reached $30 \mathrm{dBZ}$ at $0.75 \mathrm{~km}$; Fig. 3a). After the passage of the warm front, the ML height raised to $\sim 1.6 \mathrm{~km}$ (2215 UTC) (Figs. 1a, 3a). The ML is also depicted as a zone of dramatic increase of Doppler velocity (from $\sim 1$ to $>4 \mathrm{~m} \mathrm{~s}^{-1}$ ), retrieved by the $35-\mathrm{GHz}$ vertical-pointing radar (Fig. 3b), because hydrometeors may become larger in size due to coalescence and denser due to melting (Mitchell 1996; Heymsfield and Iaquinta 2000; Protat and Williams 2011).

Data from the 35-GHz vertical-pointing radar (Fig. 3a) show that the cloud-top height decreased (from 6.5 to $5 \mathrm{~km}$ ) at a mean rate of $0.24 \mathrm{~km} \mathrm{~h}^{-1}$ during the frontal passage, while the cloud-top temperature increased from $\sim-35^{\circ}$ to $\sim-25^{\circ} \mathrm{C}$, according to radiosondes (Fig. 4). The lowering of cloud-top height with time, which can be seen in Fig. $4 \mathrm{c}$ as a decrease of $\mathrm{RH}$ with time by $50 \%$ at altitudes $6-7 \mathrm{~km}$, is also perceptible from Fig. $2 \mathrm{~b}$ (3-GHz radar) and Fig. 3b (35-GHz radar). The 35-GHz radar data (Fig. 3c) show that $>50 \%$ of the pixels were considered as cloudy (where $Z_{\mathrm{H}}>-40 \mathrm{~dB} Z$ ) at altitudes $\leq 5.5 \mathrm{~km}$ for $1800-1900$ UTC. However, this height gradually decreased to 4.5 (1900-2000 UTC) and $4 \mathrm{~km}$ (2100-2200 UTC). The corresponding heights for the 3 - GHz radar were always observed $\sim 0.5 \mathrm{~km}$ lower than the $35-\mathrm{GHz}$ radar (Fig. 2b), as the 3-GHz frequency is mainly used for the detection of precipitation and not of smaller cloud particles. According to Fig. 3b, Doppler velocities between 0 and $-1 \mathrm{~ms}^{-1}$ were observed at cloud tops (height $>4 \mathrm{~km}$ ), which is consistent with weak vertical motions and slowly precipitating low-density ice crystals (like the small ice plates and columns at altitudes $>4 \mathrm{~km}$ and temperatures $<-15^{\circ} \mathrm{C}$ in Fig. 5) (Jayaweera and Cottis 1969; Heymsfield 1972; Kajikawa 1972).

To gain insight into the presence of the aforementioned features, a statistical analysis of the $Z_{\mathrm{H}}$ and $Z_{\mathrm{DR}}$ datasets is shown in Figs. 2c, 2e, and 3c. In relation to $Z_{\mathrm{H}}$ fall streaks, in Fig. $2 \mathrm{c}, Z_{\mathrm{H}}$ seems to increase between 1646 and 1932 UTC (95th percentiles of $Z_{\mathrm{H}}$ $\sim 20 \mathrm{~dB} Z$ at $2-4-\mathrm{km}$ height). At 1912-1932 UTC, although average $Z_{\mathrm{H}}$ decreased significantly to $\sim 10 \mathrm{~dB} Z$, high- $Z_{\mathrm{H}}$ 95th-percentile values $(>20 \mathrm{~dB} Z)$ were observed at $2-4 \mathrm{~km}$, highlighting the presence of discrete GCs. This is also demonstrated by the $35-\mathrm{GHz}$ radar dataset, as 95th percentiles of $Z_{\mathrm{H}-35}$ around the ML were enhanced at 2000 UTC (from 15 to $\sim 30 \mathrm{dBZ}$ ). This $Z_{\mathrm{H}-35}$ increase, as well as the enhanced 95 th percentiles at $2-4 \mathrm{~km}$, implies the occurrence of more frequent and more intense, but spatially restricted, GCs, which occasionally affected the ML echo (Fig. 3d). This is also demonstrated by the fact that $Z_{\mathrm{H}-35}$ increased in the ML and decreased at $2-4 \mathrm{~km}$ with time, while 95th-percentile signals at $2-4 \mathrm{~km}$ remained significantly high $(\sim 15 \mathrm{dBZ})$. In addition, the verticalpointing radar at 1900-2030 UTC observed larger Doppler velocities $\left(-2\right.$ to $\left.-3 \mathrm{~m} \mathrm{~s}^{-1}\right)$, compared to the previous time period at $0.7-3-\mathrm{km}$ height, which indicates the existence of denser hydrometeors (like the large ice particles at altitudes $<3.5 \mathrm{~km}$ in Fig. 5).

Switching focus to $Z_{\mathrm{DR}}$ fall streaks, these features can be observed in Fig. 2e as local $Z_{\mathrm{DR}}$ maxima at altitudes of $\sim 4 \mathrm{~km}$ (slightly higher than $Z_{\mathrm{H}}$ fall streaks). The $Z_{\mathrm{DR}}$ fall streaks manifest mainly as perturbations to the 95th percentile $(0.5-2 \mathrm{~dB})$ relative to the rest of the profile, affecting also the mean value (0.5-1 dB). The $Z_{\mathrm{DR}}$ fall streaks are mainly observed during the second half of the observing period, 1800-1932 UTC.

The WCB was a clearly identifiable dynamical feature that likely "fed" the cloud system with water vapor. It is presented, in the vertical-pointing radar dataset, as a zone of Doppler velocity $\sim 0 \mathrm{~m} \mathrm{~s}^{-1}$, where strong westerlies (typically $>20 \mathrm{~m} \mathrm{~s}^{-1}$ ) of the WCB advected the hydrometeors almost horizontally (Fig. 3b). While the wind speed profiles suggest significant stratification at all times (Fig. 4d), it seems that the highest wind speeds were observed near cloud top, where relative humidity (Fig. 4c) and cloudiness (Fig. 3c) dramatically decrease. The main region of high wind speeds $\left(20-30 \mathrm{~m} \mathrm{~s}^{-1}\right)$ (Fig. 4d) and positive wind shear (Fig. 2h) was first located at 5-6 km (1500-1600 UTC) but gradually lowered to $3.5-4.5 \mathrm{~km}$ (after 1800 UTC). However, before 1800 UTC, there were also other enhanced wind speed layers along the profile, which likely represent slight differences in air mass characteristics/origin. As an illustration, two welldistinguished layers, centered at altitudes of $\sim 2.5$ and $\sim 4 \mathrm{~km}$ at $\sim 1700$ UTC (Fig. 2f), coincided with wind speed $\left(17-20 \mathrm{~m} \mathrm{~s}^{-1}\right)$, relative humidity $(>90 \%)$, clockwise wind veering $\left(\sim 60^{\circ} \mathrm{km}^{-1}\right.$, compared to the average of $\sim 20^{\circ} \mathrm{km}^{-1}$ for altitudes $\left.0-6 \mathrm{~km}\right)$, and potential temperature $\left(\sim+9 \mathrm{~K} \mathrm{~km}^{-1}\right.$, compared to average rate of $+4 \mathrm{~K} \mathrm{~km}^{-1}$ for altitudes $0-6 \mathrm{~km}$ ) maxima (Figs. 4c-f). At the same altitudes, temperature 

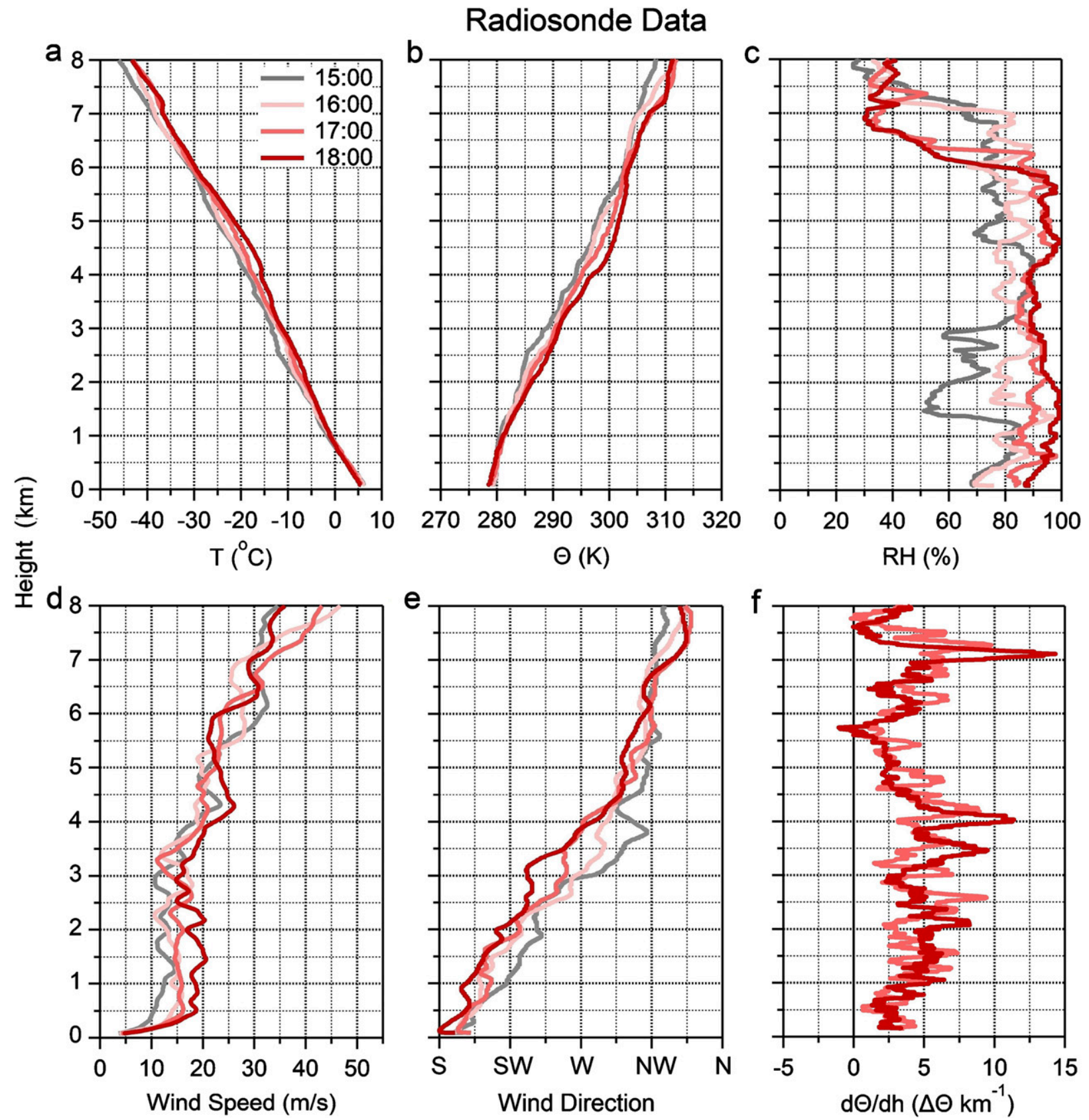

FIG. 4. Graphs demonstrating (a) temperature $\left({ }^{\circ} \mathrm{C}\right)$, (b) potential temperature $(\mathrm{K}),(\mathrm{c})$ relative humidity $(\%)$, (d) wind speed $\left(\mathrm{m} \mathrm{s}^{-1}\right)$, (e) wind direction, and (f) change of potential temperature with height obtained from radiosonde data. Different colors indicate different times and were selected to be comparable with the color scheme of Figs. 2b, 2c, 2e, 2g, 3b, 3c, and 3e.

presented the highest increase (up to $1.3^{\circ} \mathrm{Ch}^{-1}$ ) between 1500 and 1800 UTC. All the above observations reveal that there was a main warm front at $\sim 4 \mathrm{~km}$ and a possible subfrontal zone at $\sim 2.5 \mathrm{~km}$, the locations of which were associated with defined structures in the wind speed and temperature data. As a general trend, it seems that as the warm front was approaching, the various wind speed layers tended to merge (only one significant wind speed peak can be observed at $\sim 4 \mathrm{~km}$ at 1800 UTC; Fig. 4d) and were located at lower altitudes (Figs. 2g,h).

\section{Microphysical properties of the warm front}

Using in situ and remote sensing data, the microphysical properties in specific features of the warm 


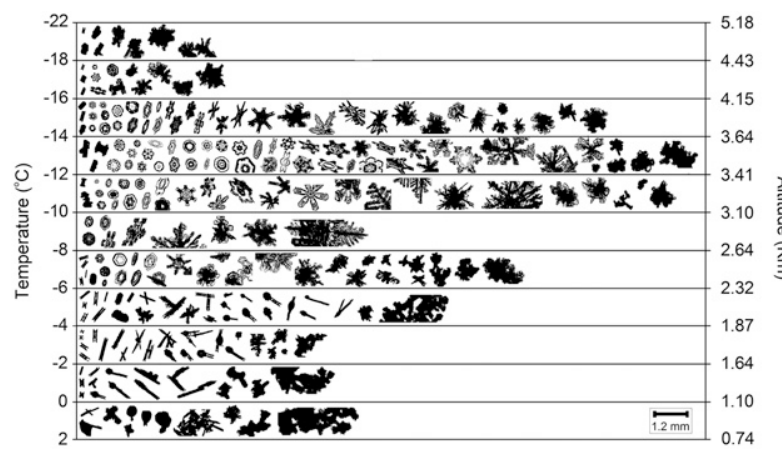

FIG. 5. Example of ice particle images captured by the 2D-S probe. Ice particles are grouped by the temperature (left axis) and altitude (right axis) at which they were observed.

frontal cloud, such as the WCB, ice fall streaks, and regions of secondary ice production, are investigated.

\section{a. The warm conveyor belt}

The WCB originated in the warm sector of the deep, low pressure system shown in Fig. 1a, and during the observing period, it intersected the surface in the Celtic Sea. It was responsible for the large-scale slantwise ascent of humid air, which led to widespread formation of mixed-phase clouds.

At 1600 UTC, CAMRa scans to the WSW identified three zones of enhanced Doppler velocity (up to $\sim 20 \mathrm{~m} \mathrm{~s}^{-1}$ ) at altitudes of 2.5, 4, and $6 \mathrm{~km}$ (Fig. 6a). These three zones caused significant vertical wind shear (up to $-12 \mathrm{~m} \mathrm{~s}^{-1} \mathrm{~km}^{-1}$ ), which could potentially release instability and form convective GCs. Similar regions of wind shear were also identified in the wind speed and direction data from radiosonde profiles (Fig. 6b). In regions where the radar scan azimuth $\left(255^{\circ}\right)$ is closely aligned with the wind speed (at altitudes $2.5-3 \mathrm{~km}$ ), the radiosonde wind speed is in good agreement with Doppler velocity.

At 1800 UTC, as the warm front approached the radar site, a broad slanted zone of high Doppler velocities (up to $23 \mathrm{~m} \mathrm{~s}^{-1}$ ) was observed spanning altitudes of $2-5 \mathrm{~km}$ (Fig. 6c). The high Doppler velocity zone at $3-5 \mathrm{~km}$ highlighted the WCB location and presented enhanced wind speed (15.6-26.0 $\mathrm{m} \mathrm{s}^{-1}$ ) and wind direction shear $\left(21^{\circ} \mathrm{km}^{-1}\right)$. The peak wind speed was located near the middle of the WCB, with two zones of wind speed and direction shear located below $\left(+8.7 \mathrm{~m} \mathrm{~s}^{-1} \mathrm{~km}^{-1}\right.$, $\left.\sim 47^{\circ} \mathrm{km}^{-1}\right)$ and above it $\left(-3.8 \mathrm{~m} \mathrm{~s}^{-1} \mathrm{~km}^{-1}, \sim+10^{\circ} \mathrm{km}^{-1}\right)$. Again, there was a good level of agreement between Doppler velocity and measured wind speed for wind directions close to the radar beam azimuth $\left(255^{\circ}\right)$ (Figs. 6a-d). Comparing and linking the Doppler velocity with radiosonde data, we estimate the main warm front location as shown in Fig. $6 c$ by the solid red line. Smaller fluctuations in Doppler velocity fields and radiosonde wind profiles indicate the presence of a small subfrontal zone located at $\sim 2 \mathrm{~km}$ (dashed red line).

At 1935 UTC, the frontal system had transited farther to the east over the ground site. At this time, the WCB was located $\sim 2 \mathrm{~km}$ closer to the surface (between 1 and $3 \mathrm{~km}$ ), being represented by a distinct zone of Doppler velocities between 17 and $25 \mathrm{~m} \mathrm{~s}^{-1}$ (Fig. 6e). Aircraft observations obtained through the WCB at this time indicate the presence of significant liquid water (Fig. 6f) (up to $0.22 \mathrm{~g} \mathrm{~m}^{-3}$ ) and cloud droplet concentrations (10$58 \mathrm{~cm}^{-3}$ ), while IWC dramatically increases outside the WCB (up to $0.044 \mathrm{~g} \mathrm{~m}^{-3}$ ). These observations support the idea that slantwise ascent from the WCB generates a large expanse of cloud containing supercooled liquid water. The lifetime and radiative properties of similar supercooled layer clouds is sensitive to the presence of ice nuclei (e.g., Pinto 1998; Jiang et al. 2000; Morrison et al. 2005; Murray et al. 2012), which can activate to form ice in the cloud, leading to poor representation in weather models.

\section{b. The generating cells}

As the warm front approached the United Kingdom, some GCs appeared in RHIs, especially after 1800 UTC. Despite the lack of in situ measurements within these features, we try to investigate their microphysics using the available radar data. In general, GCs were observed above the WCB and above a braided structure (Chapman and Browning 1998) associated with sheared wind (Fig. 7a). Sheared wind is associated with KelvinHelmholtz instability (Browning 1971; Browning et al. 1973), which is a mechanism that can trigger convection (Hogan et al. 2002).

At altitudes where GCs appeared $(4.5-6.5 \mathrm{~km})$, the rate of change in potential temperature with altitude recorded by the radiosondes at 1700 and 1800 UTC was $0-5 \mathrm{~K} \mathrm{~km}^{-1}$ (Fig. 4f). It is important that a small region of negative rate is observed at $\sim 5 \mathrm{~km}$, which coincides with the typical location of GCs, implying that GCs formed due to the release of instability through the Kelvin-Helmholtz mechanism. In the meantime, the wind speed exhibited an increasing trend with time within the WCB (4.2 km) (Fig. 4d). This increased the wind shear from $\sim 4$ to $\sim 8 \mathrm{~m} \mathrm{~s}^{-1} \mathrm{~km}^{-1}$ at 1700 and 1900 UTC, respectively, at the top layer of the WCB, which also lowered from 4.5 to $3.5 \mathrm{~km}$ (Fig. 2h). Although a radiosonde cannot provide representative data over a wide area, the above measurements indicate the occurrence of instability and a triggering mechanism that can explain the presence of GCs. As stated earlier (beginning of section 4), GCs demonstrated a core of $Z_{\mathrm{H}}>$ $10 \mathrm{~dB} Z$, which increased to $20-33 \mathrm{~dB} Z$ as the warm front approached the Chilbolton site. GCs also demonstrated 

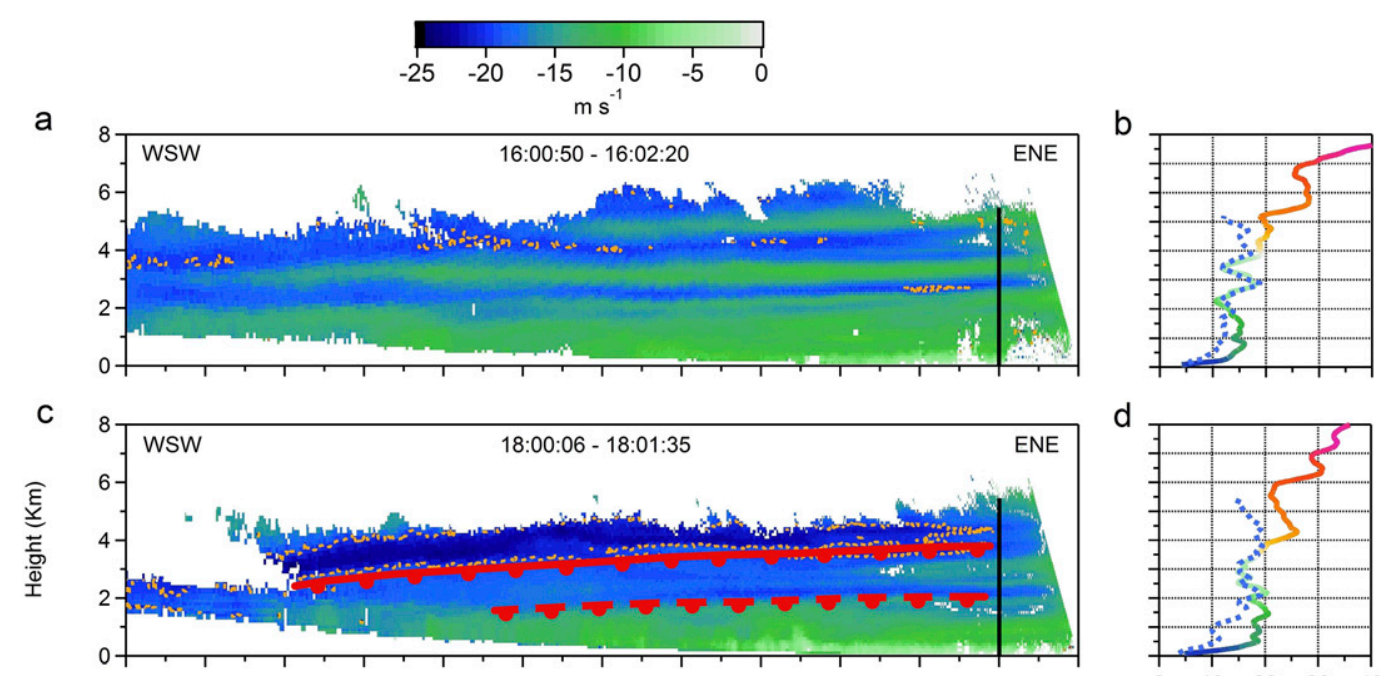

d
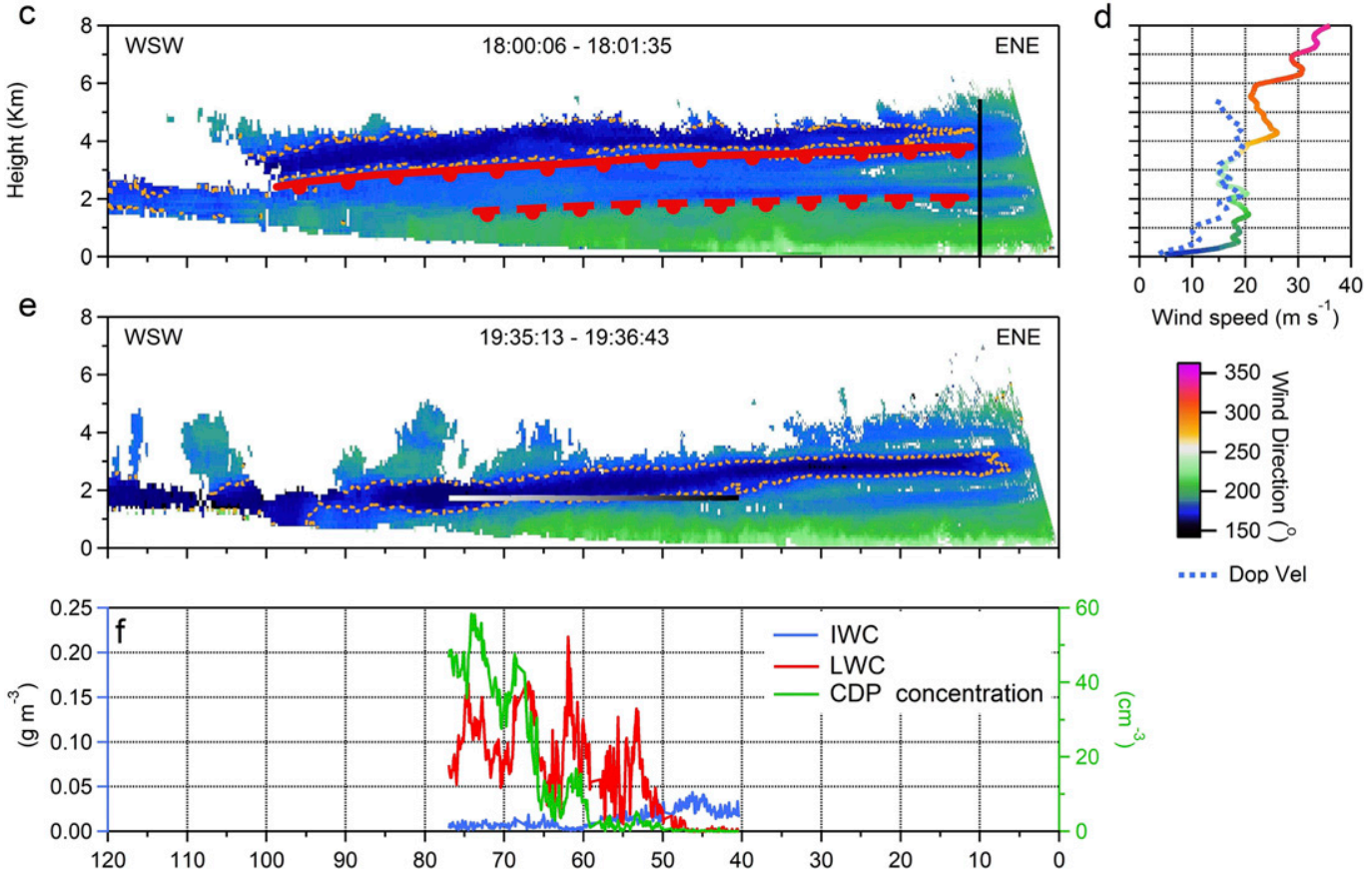

FIG. 6. Unfolded Doppler velocity $\left(\mathrm{m} \mathrm{s}^{-1}\right)$ in RHI scans for three scanning periods: (a) 1600:50-1602:20, (c) 1800: 06-1801:35, and (e) 1935:13-1936:43 UTC (the grayscale line shows the aircraft track between 1933:34 and 1940: 05-black for the initial and white for the final position). Negative values indicate flow toward the radar. The orange dashed line is the $-20 \mathrm{~m} \mathrm{~s}^{-1}$ contour. The solid red line in (c) determines the warm front boundary location and the dashed red line the possible subfront. (b),(d) Radiosonde wind speed and direction (color scale) over the Chilbolton region (shaded curve) and Doppler velocity (blue dashed line) along the vertical black line on (a),(c), respectively. (f) IWC, LWC, and cloud droplet concentrations for the corresponding aircraft track in (e) at $T \sim-1.9^{\circ} \mathrm{C}$.

high $Z_{\mathrm{DR}}$ at cloud tops $(>2 \mathrm{~dB})$, which indicates regions of newly formed ice, in which $Z_{\mathrm{DR}}$ fall streaks originated (e.g., Fig. 7e; range $=85-95 \mathrm{~km}$ ).

In Figs. $7 \mathrm{a}-\mathrm{h}$, we present the evolution of a GC. At $\sim 1928$ UTC (Figs. 7a,e), a GC was triggered at approximately $90-\mathrm{km}$ distance from CFARR, above the WCB. The Doppler velocity below the GC was $\sim-23 \mathrm{~m} \mathrm{~s}^{-1}$, but only $\sim-14 \mathrm{~m} \mathrm{~s}^{-1}$ in the newly formed $\mathrm{GC}$, indicating wind shear at the top of the WCB (Fig. 7a). The above observations suggest that the trigger that caused the formation of GCs was the wind shear at the WCB top layer (Kelvin-Helmholtz instability). Through this mechanism, significant amounts of liquid water from the WCB are lofted via turbulence and weak updrafts. In the example presented in Figs. 7i-k, the aircraft measured high cloud droplet concentration and LWC (up to $10 \mathrm{~cm}^{-3}$ and $0.3 \mathrm{~g} \mathrm{~m}^{-3}$, respectively) at the rear region of a newly formed GC (located within the WCB at $55<$ range $<65 \mathrm{~km}, 2<$ altitude $<3 \mathrm{~km}$ ). It is important to highlight that no positive values of Doppler velocity were recorded by the vertical-pointing radar (Fig. 4d). According to the CAMRa, GCs were generally forming at ranges $>30 \mathrm{~km}$ away, passing overhead the vertical-pointing radar as dissipated cells or $Z_{\mathrm{DR}} / Z_{\mathrm{H}}$ fall streaks. In addition, due to the short time of GC genesis (5-15 min) and their narrow updraft region (typically $<5 \mathrm{~km}$ ), it is not highly likely that a GC was captured overhead the radar during its genesis time. 

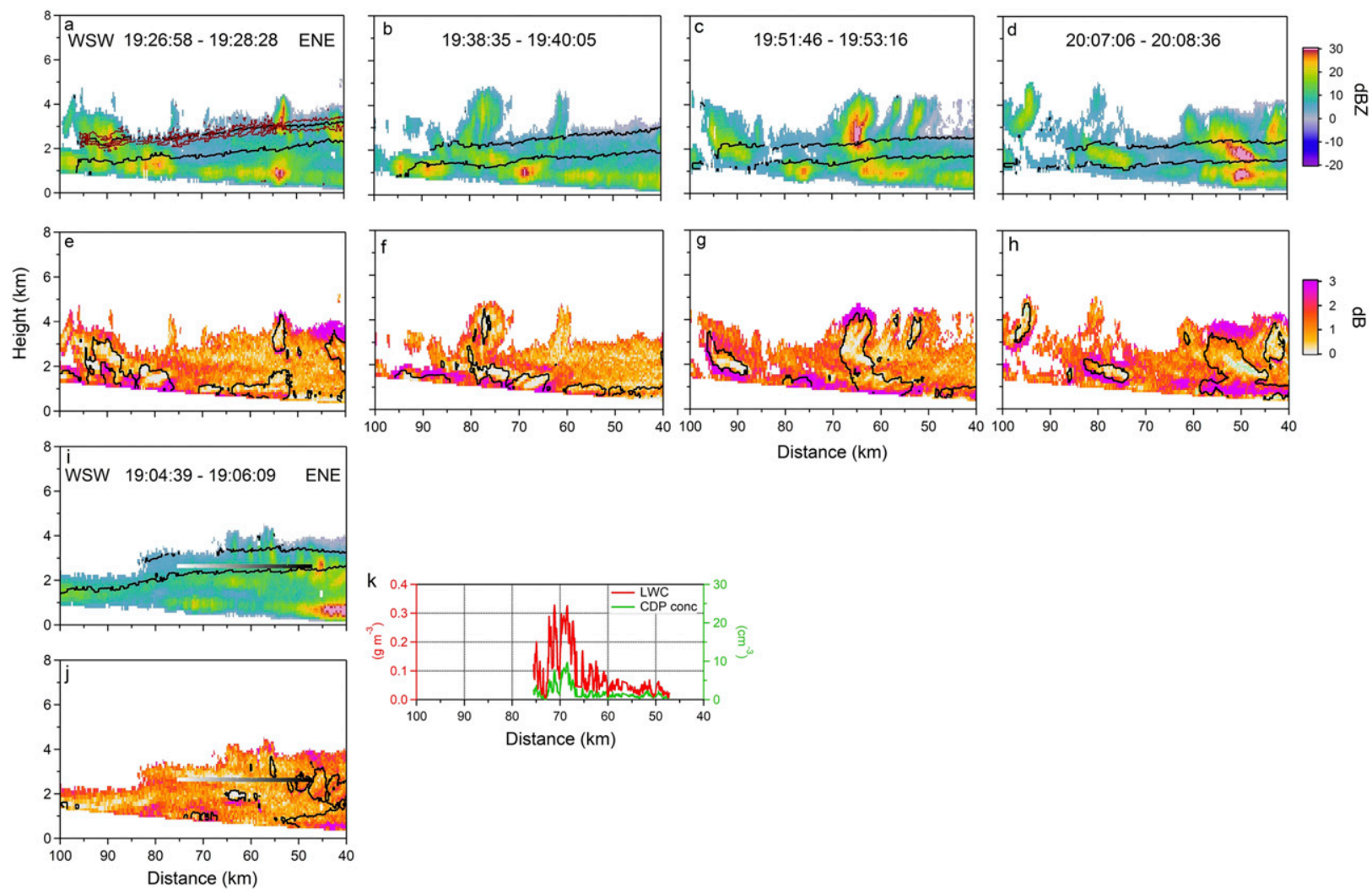

FIG. 7. RHIs of (a)-(d),(i) $Z_{\mathrm{H}}(\mathrm{dBZ})$ and (e)-(h),(j) $Z_{\mathrm{DR}}(\mathrm{dB})$. The horizontal grayscale line shows the aircraft track between 1903:00 and 1907:48 in (i),(j) (white for the final and black for the starting position). The mean temperature recorded along the track was $\sim-7^{\circ} \mathrm{C}$. The black contour line in (a)-(d) is for Doppler velocity equal to $-20 \mathrm{~m} \mathrm{~s}^{-1}$ and in (e)-(h) for $Z_{\mathrm{H}}=15 \mathrm{~dB} Z$. In (a), the red contour presents wind shear $d V / d z=7 \mathrm{~m} \mathrm{~s}^{-1} \mathrm{~km}^{-1}$. (k) LWC and cloud droplet concentration along the aircraft track in (i),(j).

The GC was further developed in height $10-20 \mathrm{~min}$ later (Figs. 7b,f and 7c,g), which caused the intensification of the aggregation and riming processes and affected the $Z_{\mathrm{H}}$ parameter $\left(Z_{\mathrm{H}}\right.$ increased to $\left.\sim 32 \mathrm{~dB} Z\right)$. At the later stage (Fig. $7 \mathrm{~g}$ ), a distinct region of very high $Z_{\mathrm{DR}}$ and low-medium $Z_{\mathrm{H}}$ was observed (up to $4 \mathrm{~dB},<17 \mathrm{~dB} Z)$ at the $\mathrm{GC}$ top. This suggests regions of newly formed (as there was not such a region earlier) pristine ice plates/dendrites at $-15^{\circ} \mathrm{C}$ (Fig. 7f) (e.g., Kobayashi 1961; Magono and Lee 1966; Schrom et al. 2015; Bailey and Hallett 2009; Schrom and Kumjian 2016). The fact that these $Z_{\mathrm{DR}}$ structures, which indicate the presence of unrimed ice particles, typically form at the later stages of GC formation suggests that they result from ice nucleation in regions where the initial convective feature has mostly decayed, but that significant regions of supersaturation still remain. Finally, as the GC core sediments/precipitates into the WCB (Figs. 7d,h), the associated $Z_{\mathrm{H}}$ structure changes from a largely vertical orientation to being more horizontally elongated due to strong westerlies within the WCB. The evolution of this GC shows the connection between fall streaks and GCs. Another example is shown in Figs. $12 \mathrm{c}$ and $12 \mathrm{f}$ $(40<$ range $<60 \mathrm{~km}, 2<$ altitude $<4 \mathrm{~km})$.

\section{c. The $Z_{\mathrm{DR}}$ and $Z_{\mathrm{H}}$ ice fall streaks}

\section{1) General CHARACTERISTICS}

At 1800 UTC, two zones with different radar polarimetric traits were detected within sheared ice fall streaks. The $Z_{\mathrm{DR}}$ fall streaks appeared as slanted zones of significantly high- $Z_{\mathrm{DR}}(>1.5 \mathrm{~dB})$ and low- $Z_{\mathrm{H}}$ $(<15 \mathrm{~dB} Z)$ values, containing pristine ice crystals (hexagonal plates and dendrites) (e.g., Andrić et al. 2013; Schrom et al. 2015; Schrom and Kumjian 2016). The $Z_{\mathrm{H}}$ fall streaks, which appeared as a zero- $Z_{\mathrm{DR}}(-0.5$ to $1 \mathrm{~dB})$ and high- $Z_{\mathrm{H}}(>15 \mathrm{~dB} Z)$ zone, were typically observed beneath a related $Z_{\mathrm{DR}}$ fall streak, containing mostly aggregated and rimed ice crystals. Essentially, these fall streaks were represented by a bipolar zone of high-low- $Z_{\mathrm{DR}}$ (or low-high $Z_{\mathrm{H}}$ ) zones [similar fall streaks have been investigated by Bader et al. (1987); Kumjian et al. (2014); Oue et al. (2015)]. These zones originate in and descend from GCs (section 5b), as ice 

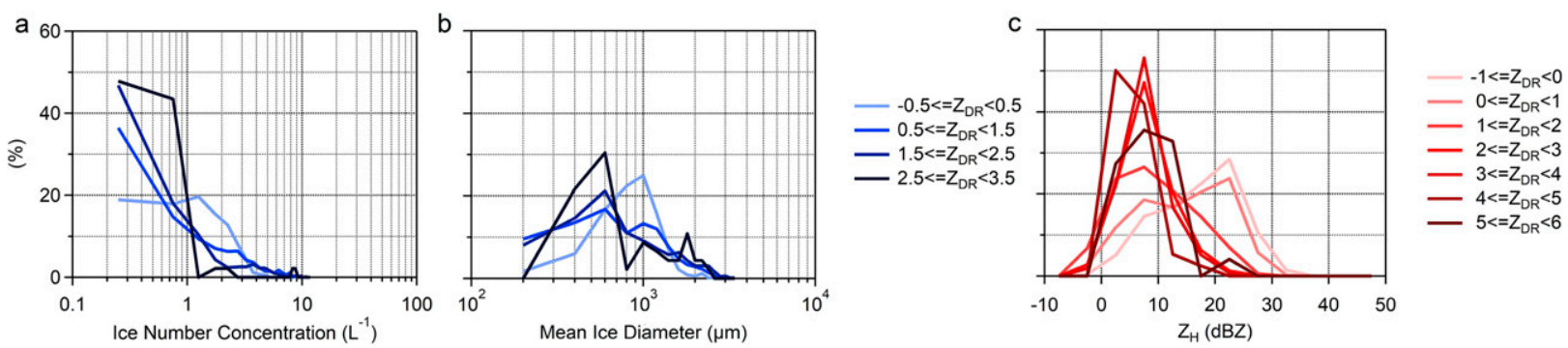

FIG. 8. Probability distribution functions of different $Z_{\mathrm{DR}}$ thresholds for in situ (a) ice number concentration, (b) mean ice particle diameter, and (c) $Z_{\mathrm{H}}$. The data used for (a),(b) come from regions where the aircraft flew through $Z_{\mathrm{DR}} / Z_{\mathrm{H}}$ fall streaks. The data used for (c) come from the 3-GHz radar for ranges of 30-90 km and elevations $>1 \mathrm{~km}$ (to avoid the ML and focus on fall streaks) between 1661:21 and 1928:28 UTC.

crystals fall into sheared flow (Kumjian et al. 2014); $Z_{\mathrm{H}}$ fall streaks can be also enhanced by pristine ice crystals precipitating into it from the overlying $Z_{\mathrm{DR}}$ fall streak.

Examining the entire in situ and polarimetric radar dataset, observations of $Z_{\mathrm{DR}}>1.5 \mathrm{~dB}$ were mostly ( $>60 \%$ of the observations) linked with low ice concentrations $\left(<2 \mathrm{~L}^{-1}\right)$ and small-sized ice particles $(<800 \mu \mathrm{m})$ (Figs. 8a,b). Taking into account previous literature (e.g., Schrom et al. 2015; Schrom and Kumjian 2016) and the fact that the data around the ML $(<1 \mathrm{~km})$ were excluded, it seems that large $Z_{\mathrm{DR}}$ values are mainly linked with small pristine ice crystals in small concentrations within the $Z_{\mathrm{DR}}$ fall streaks. Figure 8c also shows that regions of $Z_{\mathrm{DR}}<1 \mathrm{~dB}$ are partially associated (by $>45 \%$ ) with observations of $Z_{\mathrm{H}}>15 \mathrm{dBZ}$ due to $Z_{\mathrm{DR}}$ fall streaks, while regions of $Z_{\mathrm{DR}}>1 \mathrm{~dB}$ are associated (by $60 \%-70 \%$ ) with smaller $Z_{\mathrm{H}}\left(Z_{\mathrm{H}}<15 \mathrm{dBZ}\right)$ due to $Z_{\mathrm{H}}$ fall streaks. It should be highlighted that regions of lower- $Z_{\mathrm{DR}}$ values (in general, $<1.5 \mathrm{~dB}$, such as $Z_{\mathrm{H}}$ fall streaks) were observed to have a larger variety of ice particle number concentrations (from $<4$ to $10 \mathrm{~L}^{-1}$ ) and mean size (from $<500$ to $3600 \mu \mathrm{m}$ ). Smaller crystals in larger concentrations can be explained by the effects of secondary ice production (see section $5 \mathrm{~d}$ ). To conclude, although the $Z_{\mathrm{H}} / Z_{\mathrm{DR}}$ fall streak radar polarimetric boundary is not particularly clear, a rough threshold for distinguishing them could be $Z_{\mathrm{H}} \sim 15 \mathrm{dBZ}$, $Z_{\mathrm{DR}} \sim 1 \mathrm{~dB}$.

An example of the evolution of large-scale, moderately intense $Z_{\mathrm{DR}} / Z_{\mathrm{H}}$ fall streaks is illustrated in Fig. 9. The first fall streak started to form at $\sim 1549$ UTC (Figs. 9a,e), located at range $=100-110 \mathrm{~km}$ and height $=$ 4-6 km. In this region, a spatially more extensive but less intense, in terms of $Z_{\mathrm{H}}\left(Z_{\mathrm{H}}<17 \mathrm{dBZ}\right)$, GC occurred (compared to the GC investigated in section 5b). At this stage, the $Z_{\mathrm{DR}}$ fall streak was relatively modest, occasionally approaching $1-2.5 \mathrm{~dB}$. The corresponding $Z_{\mathrm{H}}$ structure was also relatively modest, exhibiting values of $\sim 15 \mathrm{~dB} Z$, which was an enhancement of $\sim 10 \mathrm{~dB} Z$ over the $Z_{\mathrm{DR}}$ fall streak. As the wind speed in the WCB appears to increase $\sim 25$ min later (1613 UTC; Figs. 9b,f), both $Z_{\mathrm{DR}}$ and $Z_{\mathrm{H}}$ fall streak signals become more obviously enhanced (up to $2.7 \mathrm{~dB}$ and $24.5 \mathrm{~dB} Z$, respectively). The $Z_{\mathrm{H}}$ fall streak coincided with a region of $Z_{\mathrm{DR}} \sim 0 \mathrm{~dB}$ and is first observed in a region of enhanced Doppler velocity $\left(>20 \mathrm{~m} \mathrm{~s}^{-1}\right)$. As this region was part of the WCB (which transported large amounts of liquid water), it is highly likely that ice crystals became intensely rimed and less oblate within it. Ten minutes later ( $\sim 1623$; Figs. 9c,g), the $Z_{\mathrm{H}}$ fall streak was represented by $-0.6<Z_{\mathrm{DR}}<1.5 \mathrm{~dB}$ and $Z_{\mathrm{H}}>15 \mathrm{dBZ}$, containing large $(\sim 984 \mu \mathrm{m})$ aggregated and heavily rimed dendrites (Fig. 9i) in concentrations of $\sim 1.4 \mathrm{~L}^{-1}$ (Fig. 9m). The $Z_{\mathrm{H}}$ fall streak was an almost-glaciated zone, typically exhibiting $\mathrm{LWC} \sim 0 \mathrm{~g} \mathrm{~m}^{-3}$ and $\mathrm{IWC}>0.01 \mathrm{~g} \mathrm{~m}^{-3}$.

After a further $30 \mathrm{~min}(\sim 1655)$, the fall streak was fully developed, demonstrating the largest length of all the observed fall streaks $(\sim 60 \mathrm{~km})$ during the day and an expansion rate of $\sim 17 \mathrm{~m} \mathrm{~s}^{-1}$. Although the $Z_{\mathrm{DR}}$ fall streak was characterized by $Z_{\mathrm{H}}<15 \mathrm{~dB} Z$ and $Z_{\mathrm{DR}}>1 \mathrm{~dB}$ due to small concentrations of ice dendrites and plates (Figs. 9d,h), it was actually divided into two sub-fall streaks: one (Figs. 9d,h; range $=65-85 \mathrm{~km}, Z_{\mathrm{DR}}>1.5 \mathrm{~dB}, T \sim-13^{\circ} \mathrm{C}$ ) with small $(\sim 580 \mu \mathrm{m})$ ice plates (Fig. 9j; frames $3-4)$ and another (Figs. 9d,h; range $=55-65 \mathrm{~km}, Z_{\mathrm{DR}} \sim 1.5 \mathrm{~dB}$, $\left.T \sim-13.5^{\circ} \mathrm{C}\right)$ with large $(400-1400 \mu \mathrm{m})$ ice stellars/ dendrites/dendrite aggregates (Fig. 9j; first two frames; Fig. 9n), both in small concentrations $\left(<1\right.$ and $<5 \mathrm{~L}^{-1}$, respectively). We speculate that the sub-fall streak, which contained ice dendrites/stellars, formed when small and light ice plates drifted away from the initial $Z_{\mathrm{DR}}$ fall streak due to strong westerlies and remained within the WCB for a longer time. As a result, these plates grew into ice dendrites/stellars due to the high supersaturation regime at $\sim-13^{\circ} \mathrm{C}$ (Fig. 9d) (Bailey and Hallett 2009). In the transitional zone between the $Z_{\mathrm{DR}}$ and $Z_{\mathrm{H}}$ fall streak, (Figs. $9 \mathrm{~d}, \mathrm{~h}$; range $=90 \mathrm{~km}$, height $=3.5 \mathrm{~km}$ ), small graupel particles mixed with slightly larger pristine 

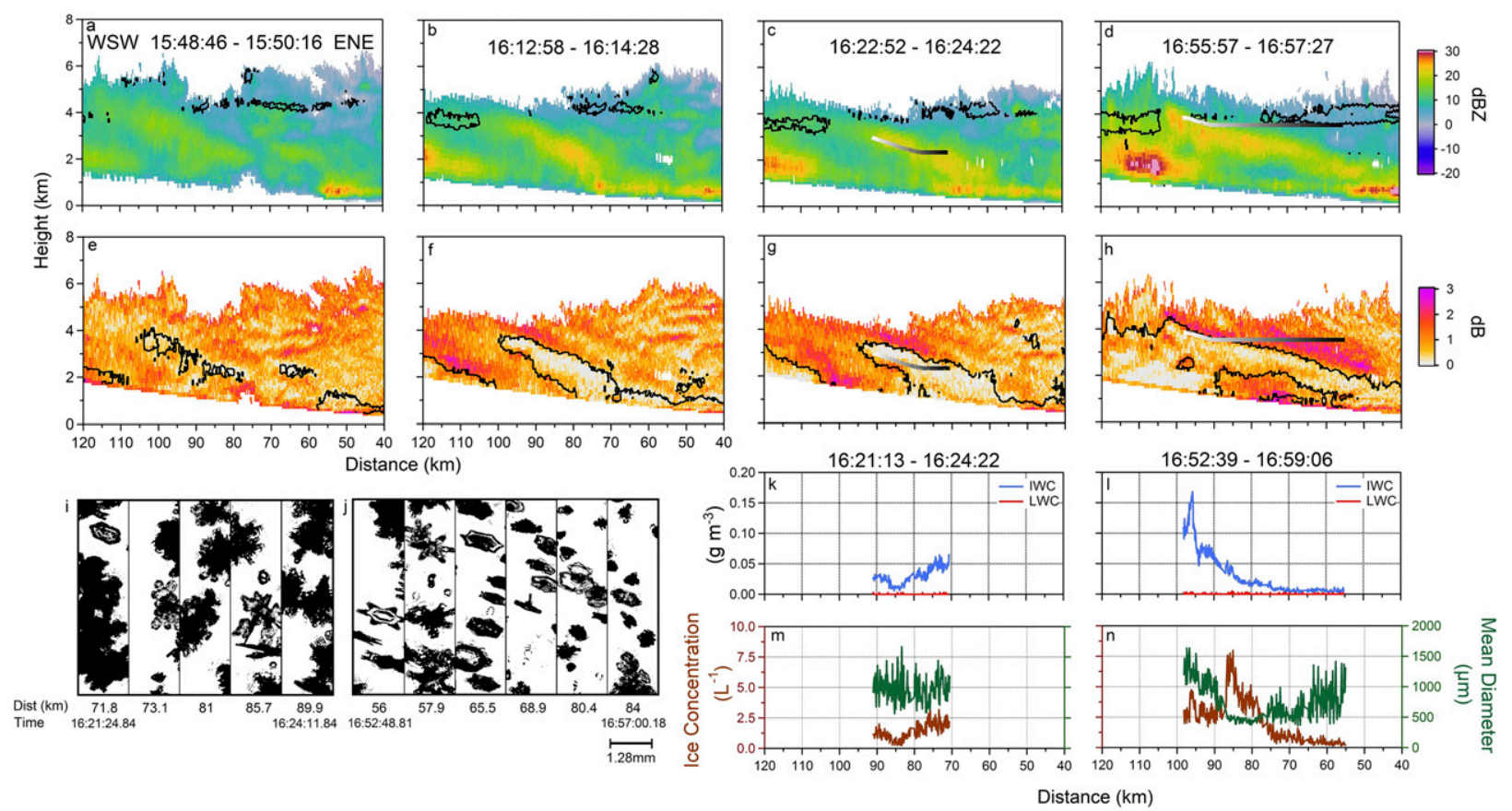

FIG. 9. RHIs of (a)-(d) $Z_{\mathrm{H}}(\mathrm{dBZ})$ and (e)-(h) $Z_{\mathrm{DR}}(\mathrm{dB})$. The grayscale line shows the aircraft track between $1621: 13$ and 1624 : 22 UTC in (c),(g) and 1652:39 and 1659:06 UTC in (d),(h) (white for the final and black for the starting position). The black isoline in (a)-(d) is for Doppler velocity equal to $-20 \mathrm{~m} \mathrm{~s}^{-1}$ and in (e)-(h) for $Z_{\mathrm{H}}=15 \mathrm{~dB} Z$. (i), (j) 2D-S images captured during the flight track at $(\mathrm{c}),(\mathrm{g})$ and $(\mathrm{d}),(\mathrm{h})$ at temperatures $-7.8^{\circ}-12.9^{\circ} \mathrm{C}$, respectively. $(\mathrm{k}),(\mathrm{m})$ IWC/LWC and ice number concentration/ice mean diameter, respectively, for the aircraft track in (c),(g). (l),(n) As in (k),(m), but for the aircraft track in (d), (h).

plates were observed in small sizes $(\sim 460 \mu \mathrm{m})$, but in larger concentrations (up to $8 \mathrm{~L}^{-1}$; Fig. 9j; last two frames). In total, although this enhanced $Z_{\mathrm{DR}}$ fall streak reached the ML retaining its characteristics, there was a decrease of $Z_{\mathrm{DR}}$ slightly above the ML, presumably due to aggregation.

An important conclusion that arises from both sections $5 b$ and $5 c(1)$ is that the slope of the fall streaks increased as the warm front was approaching. In particular, the slope of the $Z_{\mathrm{DR}}$ fall streak at 1927 UTC (Figs. $7 \mathrm{a}, \mathrm{e}$ ) was $\sim 5^{\circ}$, compared to $\sim 3^{\circ}$ and $\sim 7^{\circ}$ at earlier (1656 UTC) and later (2007 UTC; Fig. 7d) times. It seems that the wind speed intensity of the WCB (discussed in sections 4 and 5a) and, thus, the wind shear intensity at its upper boundary, played an important role in the formation and shape of the fall streaks. Thus, stronger wind shear might cause stronger updrafts, forming larger and heavier hydrometeors in a shorter period of time, which fall faster toward the surface.

\section{2) THE IMPACT OF THE $Z_{\mathrm{H}}$ FALL STREAK ON THE SURFACE PRECIPITATION}

The identification of the $Z_{\mathrm{H}}$ fall streak is very important, as it is directly related to precipitation enhancement at the surface. In Fig. 10, we present the evolution of the $Z_{\mathrm{H}} / Z_{\mathrm{DR}}$ fall streak dipole, which was described in section $5 \mathrm{c}(1)$, with the corresponding rain rate product from the Met Office operational radar network (NIMROD).

The $Z_{\mathrm{H}}$ fall streak remained elongated (length $\sim 60 \mathrm{~km}$ ) for $\sim 30 \mathrm{~min}$ (1656-1717 UTC) before dissipating, exhibiting up to $Z_{\mathrm{H}} \sim 28 \mathrm{dBZ}$. In the initial stages (1705 UTC; Figs. 10a,d), it appeared to be moving slantwise downward, being represented by $Z_{\mathrm{H} \_3 \mathrm{GHz}}>$ $20 \mathrm{~dB} Z$ and $Z_{\mathrm{DR}} \sim 0 \mathrm{~dB}$. As the $Z_{\mathrm{H}}$ fall streak evolved over the next hour, ice crystals moved slantwise downward, with aggregation and riming leading to greater and greater enhancements of the $Z_{\mathrm{H}}$ signal. At 1804 UTC, a region of significantly high $Z_{\mathrm{H}}(30-47 \mathrm{dBZ})$ was observed at the ML $(\sim 0.7 \mathrm{~km})$. Such enhanced $Z_{\mathrm{H}}$ values imply heavy aggregation due to higher temperatures $\left(>-3.5^{\circ} \mathrm{C}\right.$; Fig. $\left.2 \mathrm{~d}\right)$ and, thus, "stickier" ice crystals. Comparing the surface rain rate graphs (Figs. 10i-1) with the RHIs, it seems that the surface precipitation is strongly affected by the $Z_{\mathrm{H}}$ fall streak. In particular, the rain rate increased (at range $=30 \mathrm{~km}$; Figs. 10i-l) from $<1$ to $5 \mathrm{~mm} \mathrm{~h}^{-1}$. This suggests that fall streaks that are initiated near cloud top and develop over time scales 


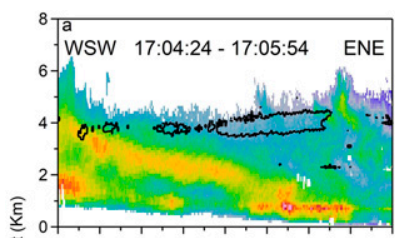

喜 8
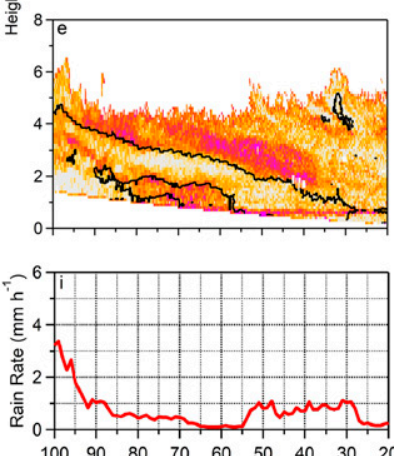
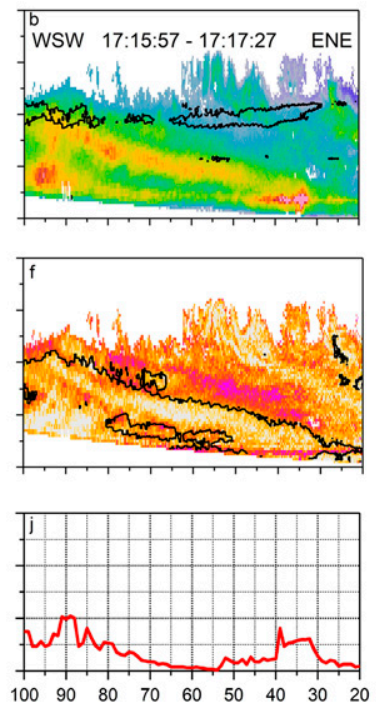
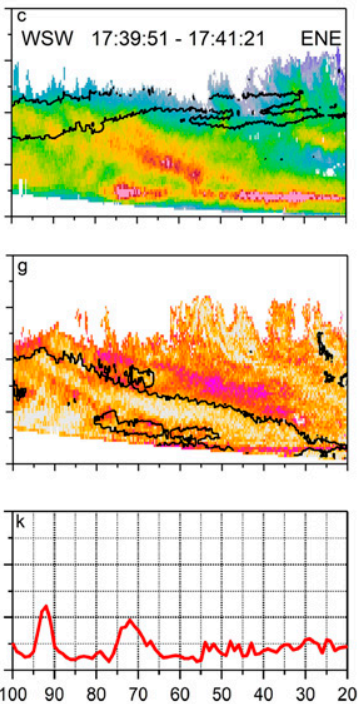
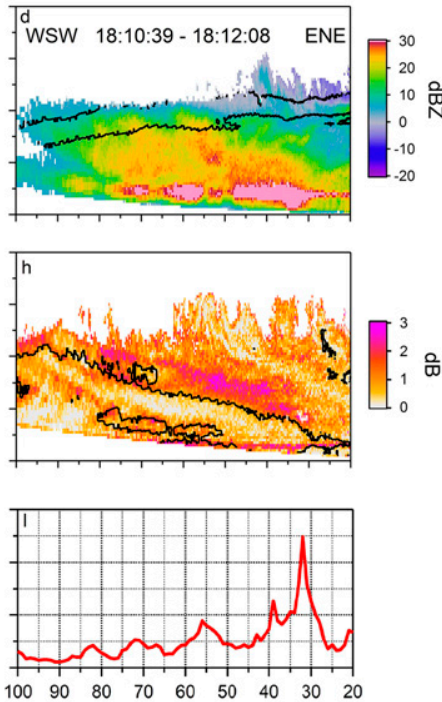

FIG. 10. As in Fig. 9. (i)-(l) Surface rain rate (NIMROD) along the radar range of the RHIs in (a),(e); (b),(f); (c),(g); and (d),(h), respectively.

of approximately an hour have a significant impact on surface precipitation rates downstream.

Finally, although a copolar correlation coefficient $\rho_{\mathrm{HV}}$ was not available in order to estimate the ML height (e.g., Giangrande et al. 2008; Boodoo et al. 2010), $Z_{\mathrm{DR}}$ $(2-4 \mathrm{~dB})$ peaked around the ML at different heights in $($ range $=32 \mathrm{~km})$ and out $($ range $=25 \mathrm{~km})$ of the $Z_{\mathrm{H}}$ fall streak (Fig. 11). In particular, at 1800 UTC, the ML was located at $0.8 \mathrm{~km}$ (Fig. $4 \mathrm{a}$ ), which broadly agrees with the
$Z_{\mathrm{DR}} / Z_{\mathrm{H}}$ peak (Brandes and Ikeda 2004; Houze 2014, p. 144) of the $25-\mathrm{km}$ vertical profiles (Fig. 11, green lines). However, a slight lowering of the $Z_{\mathrm{DR}}$ peak height was observed within the enhanced $Z_{\mathrm{H}}$ region (by 0.2 $0.4 \mathrm{~km}$ ). The local depression of the melting layer was possibly caused by the melting of large aggregates (Stewart 1984; Stewart et al. 1984; Oraltay and Hallett 2005; Griffin et al. 2014). This is important, as $\sim 0^{\circ} \mathrm{C}$ isothermal layers can be produced close to the surface, allowing (partially
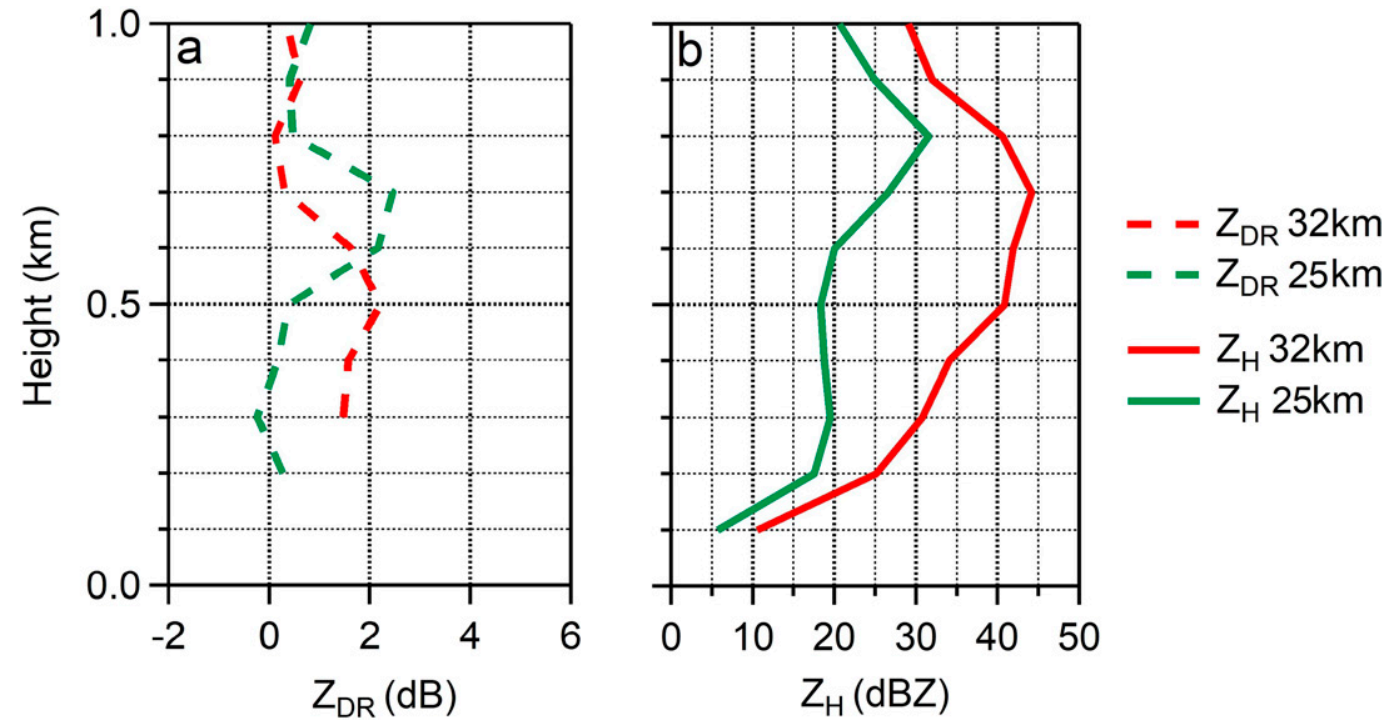

FIG. 11. (a) $Z_{\mathrm{DR}}$ and (b) $Z_{\mathrm{H}}$ profiles (0-1-km height) from data taken from the radar scans $10 \mathrm{~d}$ and $10 \mathrm{~h}$. Green curves depict the profiles out $($ range $=25 \mathrm{~km})$ and red curves within the $Z_{\mathrm{H}}$ fall streak $($ range $=32 \mathrm{~km})$. 

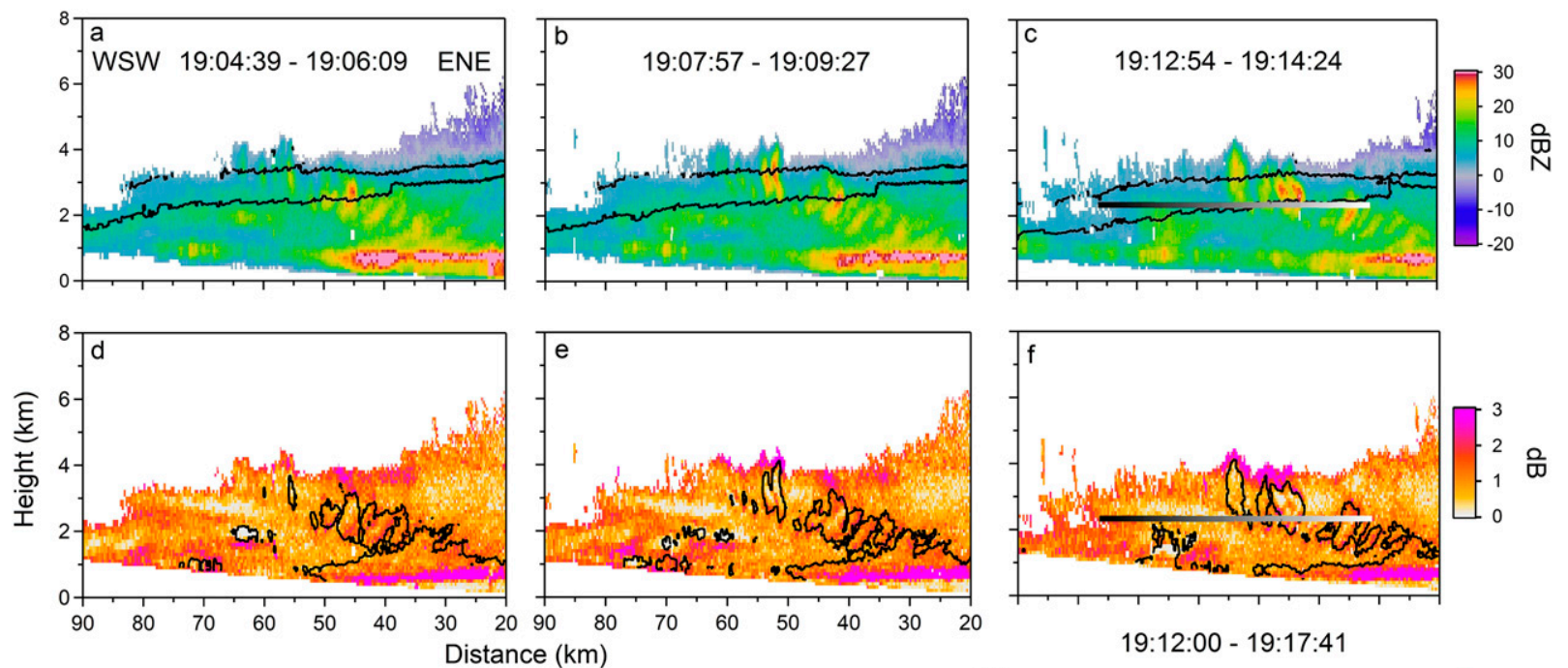

19:12:00 - 19:17:41
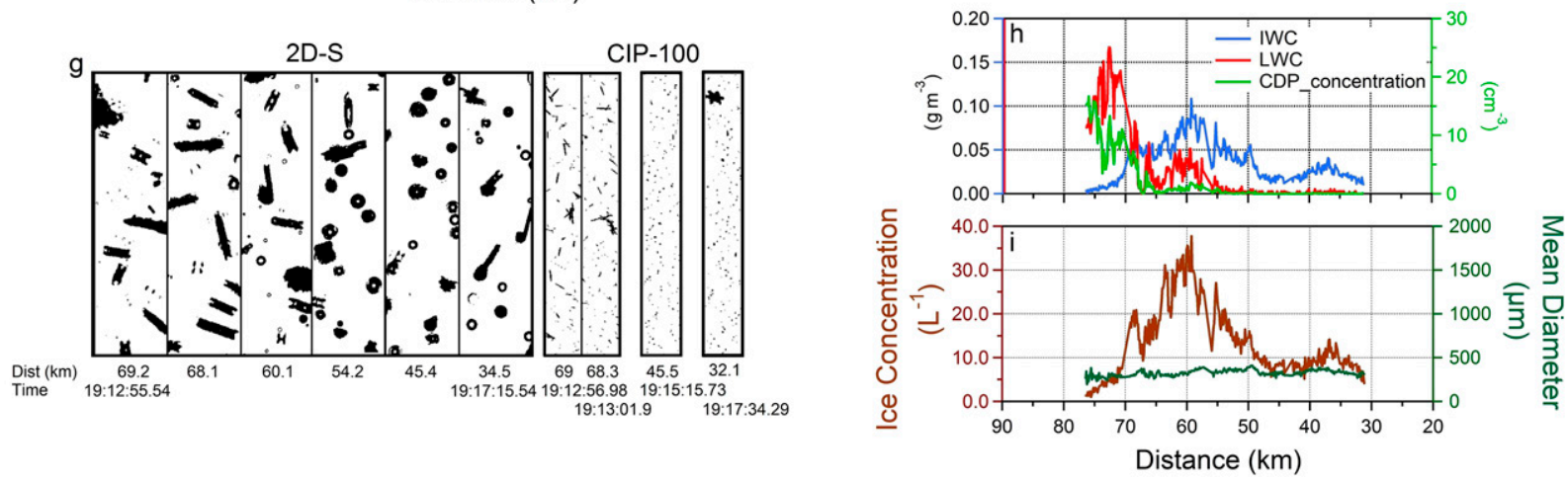

FIG. 12. As in Fig. 9. (g) 2D-S and CIP-100 images. The time and range from the Chilbolton radar are indicated at the bottom of the figure in order to be comparable with the radar scans. (h) Green curve shows the cloud droplet concentration. The mean temperature along the aircraft track was $\sim-4.8^{\circ} \mathrm{C}$.

melted) ice to precipitate (Findeisen 1940; Szeto et al. 1988; Ryzhkov et al. 2011; Griffin et al. 2014).

\section{d. Secondary ice in the $Z_{\mathrm{H}}$ fall streak}

In this section, we try to analyze concurrent in situ and radar data in order to detect, determine, and investigate the characteristics of regions that appear to be greatly influenced by secondary ice processes.

Between 1912:54 and 1917:42 UTC, the aircraft passed through a region (range $=50-70 \mathrm{~km}$ ) of lowmedium $Z_{\mathrm{H}}(8-12 \mathrm{~dB})$ and low $Z_{\mathrm{DR}}(0.5-1 \mathrm{~dB})$, which was located at the entrance of the WCB. Although this region was located within a weak signal cloud top, we speculate that this region is a mature/dissipated $Z_{\mathrm{H}}$ fall streak. At the rear of this mature $Z_{\mathrm{H}}$ fall streak (range $=$ $65-80 \mathrm{~km}$ ), which was located within the WCB entrance (Doppler velocity $>20 \mathrm{~m} \mathrm{~s}^{-1}$ ), the aircraft measured enhanced LWC and cloud droplet concentration (up to $0.17 \mathrm{~g} \mathrm{~m}^{-3}$ and $16.7 \mathrm{~cm}^{-3}$, respectively). In contrast, at the bottom of the WCB (range $=50-65 \mathrm{~km}$ ), both cloud droplet concentration and LWC decreased by $10 \mathrm{~cm}^{-3}$ and $0.10 \mathrm{~g} \mathrm{~m}^{-3}$, respectively. This liquid water removal may imply intense riming, which is a mechanism assisting in ice multiplication (Mossop and Hallett 1974; Choularton et al. 1978, 1980). The occurrence of small $(\sim 300 \mu \mathrm{m}$ in average) ice columns (Fig. 12g; 2D-S frames 1-4) in high ice number concentrations (up to $\left.37.8 \mathrm{~L}^{-1}\right)$ and the enhanced IWC $\left(0.11 \mathrm{~g} \mathrm{~m}^{-3}\right)$ observed at temperatures $\sim-4.8^{\circ} \mathrm{C}$ imply that Hallett-Mossop is the possible ice multiplication mechanism here. Some aggregated ice columns that were observed at range $=65$ $80 \mathrm{~km}$ (Fig. 12g; CIP-100 frames 1-2) formed due to the occurrence of ice columns within a region of high LWC.

Farther to the east (Figs. 12c,f,h,i), a region of quasispherical rimed ice particles (Fig. 12g; 2DS frames 4-5, CIP-100 frame 3) and supercooled water drops mixed with some ice columns (range $=43-55 \mathrm{~km} ; T \sim-4^{\circ} \mathrm{C} ; Z_{\mathrm{H}}$ up to $28.6 \mathrm{~dB}$ and $Z_{\mathrm{DR}} \sim 0.5-1 \mathrm{~dB}$ ) was observed, followed by another region of mostly ice columns (range $=31-43 \mathrm{~km}$; $T \sim-5^{\circ} \mathrm{C}$ ). As this region belonged to a short and newly 
formed $Z_{\mathrm{H}}$ fall streak originating in the core of a GC (range $\sim 53 \mathrm{~km}$, altitude $\sim 3 \mathrm{~km}$ ), processes such as riming and ice multiplication could be at early stages. This may explain the increased, but lower than the previous secondary ice region, ice concentrations (up to $14.1 \mathrm{~L}^{-1}$ ). Decreased LWC $\left(<0.005 \mathrm{~g} \mathrm{~m}^{-3}\right)$ and cloud droplet concentration $\left(<0.4 \mathrm{~cm}^{-3}\right)$ could be measured due to riming process and the aircraft position (outside the WCB). It should be noted that some pristine ice crystals from the $Z_{\mathrm{DR}}$ fall streak above $($ range $=40-50 \mathrm{~km})$ rimed (an example in Fig. 12; CIP-100 frame 4) and became heavier when they moved into the WCB. As a result, they might fall into the $Z_{\mathrm{H}}$ fall streak, which was finally characterized by small quasi-spherical (and possibly mixed phase) ice particles/supercooled water drops, but also of ice columns and ice lollies (Keppas et al. 2017).

\section{Conclusions}

On 21 January 2009, multiple frontal zones affected the U.K. weather due to a maturing depression, which originally formed over the North Atlantic Ocean. In the work presented, the dynamics and microphysics of mixed-phase clouds, with embedded convective elements, associated with the warm front of this system are investigated, comparing high-resolution $\left(0.28^{\circ}\right.$ beam $)$ dual-polarization S-band radar with in situ aircraft data. The latter data collected by $2 \mathrm{D}-\mathrm{S}$ probe (providing better resolution than $2 \mathrm{D}-\mathrm{C}$ ) were used together with CIP-100 probe data in order to provide a wider size range of measured particles. It should be noted that this is the first time that a warm front is comprehensively investigated with high-resolution data.

A few studies previously investigated warm fronts and GCs, comparing both in situ and radar datasets. Here, we discuss some of their results, which generally come to an agreement with the results of the present study. Herzegh and Hobbs (1980) found that large ice particles within GCs grew by riming, deposition, and aggregation as occurred in $Z_{\mathrm{H}}$ fall streaks. They also suggested that GCs work as feeders of ice to stratiform clouds below. According to Matejka et al. (1980), as GCs mature, they tend to be glaciated. They supported that surface precipitation is mainly associated with embedded convection in warm fronts. Hogan et al. (2002) demonstrated some evidence that embedded convection within a warm front is triggered by Kelvin-Helmholtz instability. However, they found that embedded convection was linked with narrow, vertical high- $Z_{\mathrm{DR}}$ zones of ice columns, which coincided with updrafts and was a feature that was not observed in the present study. Murakami et al. (1992) observed only a shallow layer of supercooled droplets above the warm frontal zone. Additionally, they

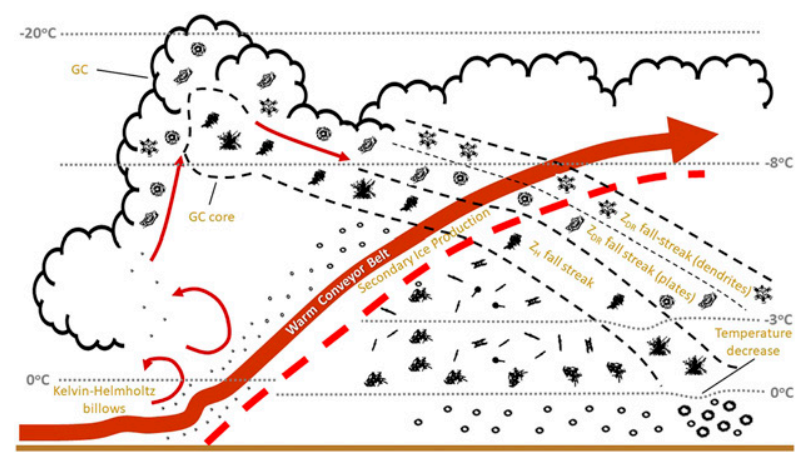

FIG. 13. A schematic representation summarizing the investigated processes and polarimetric signatures of the frontal clouds observed.

found that GCs provided a favorable environment for ice crystals to grow rapidly, which agrees with Plummer et al. (2014). Finally, Plummer et al. (2015) noticed that ice mainly grew in regions below GCs, where enhanced moisture was observed.

As a conclusion, the general structure of the warm front is schematically summarized in Fig. 13, according to the airborne in situ and ground-based polarimetric radar measurements. The main conclusions of the study are outlined as follows.

Regarding the macroscopic characteristics of the investigated warm front:

- The height of cloud tops gradually decreased from 6 to $4.5 \mathrm{~km}$ as the warm front was approaching. Cloud-top temperatures were, generally, $>-25^{\circ} \mathrm{C}$, which implies that the ice in the cloud system was formed via primary heterogeneous processes and potentially enhanced by secondary multiplication processes.

- The height of the $0^{\circ} \mathrm{C}$ level, or the melting layer (ML), was first located at $0.7 \mathrm{~km}$, rising by almost $1 \mathrm{~km}$ after the passage of the warm front.

- The horizontal dimension of the cloud mass was larger than $120 \mathrm{~km}$, the maximum range of the RHIs presented in this work.

The cloud mass consisted of distinctive features that demonstrated definite radar polarimetric and/or microphysical characteristics. These features are

- The warm conveyor belt (WCB), initially depicted by a group of multiple zones of enhanced Doppler velocity. These multiple zones merged into a single one, which decreased in altitude as the warm front moved farther inland, away from the coast. High radar Doppler velocities (20-30 $\left.\mathrm{m} \mathrm{s}^{-1}\right)$ and radiosonde wind speeds (up to $26 \mathrm{~m} \mathrm{~s}^{-1}$ ) were recorded within the WCB, presenting, essentially, a fair agreement for wind directions along the radar azimuth. The WCB 
was vitally important for transporting large amounts of liquid water (up to $0.37 \mathrm{~g} \mathrm{~m}^{-3}$ ) into the system, offering at the same time an ideal regime for secondary ice production at temperatures $\sim-6^{\circ} \mathrm{C}$.

- The generating cells (GCs), formed at the unstable (based on potential temperature profiles) layer above the WCB, where vertical wind shear triggered KelvinHelmholtz instability. The GCs were represented by a core of high $Z_{\mathrm{H}}(10-33 \mathrm{~dB} Z) / \sim 0-\mathrm{dB} Z_{\mathrm{DR}}$ and a shell of low $Z_{\mathrm{H}}(<10 \mathrm{~dB} Z) /$ high $Z_{\mathrm{DR}}$ (up to $4 \mathrm{~dB}$ ).

- The ice fall streaks, formed as GCs were moving into a sheared flow caused by the WCB. The strong westerlies "converted" the GCs' high- $Z_{\mathrm{DR}}$ shells and high$Z_{\mathrm{H}}$ cores into an ice fall streak, which consisted of two individual fall streaks with different polarimetric characteristics: a $Z_{\mathrm{DR}}$ and a $Z_{\mathrm{H}}$ fall streak, respectively. Ice fall streaks exhibited lengths of up to $60 \mathrm{~km}$ and slope of $3^{\circ}$, which increased with time (up to $7^{\circ}$ ) due to the intensification of the GCs. The $Z_{\mathrm{DR}}$ fall streaks were divided into two low- $Z_{\mathrm{H}}(<15 \mathrm{~dB} Z)$ subzones: (i) a zone of ice plates with $Z_{\mathrm{DR}}>1.5 \mathrm{~dB}$ and (ii) a zone of stellars/dendrites with $Z_{\mathrm{DR}} \sim 1.5 \mathrm{~dB}$, which might form from small ice plates that were moving from GC shells to the high supersaturated regions of the WCB. As icing can be harmful for aviation in dendritic ice regions, this can help to improve existing icing detection algorithms (Serke et al. 2008; Pitertsev and Yanovsky 2011; Ellis et al. 2012). Beneath the $Z_{\mathrm{DR}}$ fall streaks, $Z_{\mathrm{H}}$ fall streaks were represented by high $Z_{\mathrm{H}}(>15 \mathrm{~dB} Z)$ and $Z_{\mathrm{DR}} \sim 0 \mathrm{~dB}$, consisting mostly of rimed and/or aggregated ice crystals in variable sizes (from $<500$ to $3600 \mu \mathrm{m}$ ) and concentrations (from $<4$ to $>10 \mathrm{~L}^{-1}$ ). The $Z_{\mathrm{H}}$ fall streaks that form higher up in the clouds can affect the surface precipitation. The time and spatial evolution depends on the profile of wind direction and speed in the clouds. As an illustration, a case where a $Z_{\mathrm{H}}$ fall streak enhanced the surface precipitation by $4 \mathrm{~mm} \mathrm{~h}^{-1}$ an hour after its genesis was presented.

- The secondary ice regions, which presented large ice concentrations (up to $37.8 \mathrm{~L}^{-1}$ ) and mostly consisted of ice columns. Such regions were located within the intersection region of the $Z_{\mathrm{H}}$ fall streaks with the $\mathrm{WCB}$, where riming was intense at temperatures $\sim-5^{\circ} \mathrm{C}$, and liquid water was dramatically depleted, potentially affecting the cloud lifetime.

In the present paper, both heterogeneous ice nucleation and secondary ice formation were observed in mixed-phase clouds, which are highly uncertain processes. Heterogeneous ice nucleation plays an important role in the formation of GCs, as new ice forms from freezing liquid water transported aloft along the rear updraft region of GCs. As in situ measurements within GCs and ice fall streaks are limited, more observations should be performed aimed at investigation of the cloud processes (aggregation, riming, and ice multiplication) in order to obtain a deeper understanding of cloud microphysics. Except for observing real GCs, they could also be created and observed in laboratories. Comprehensive datasets, which could describe the structure and evolution of such clouds, could be used for the validation of complex microphysics models (Stoelinga et al. 2003; Keeler et al. 2016a).

Acknowledgments. The APPRAISE-Clouds program was funded by NERC (Grant NE/E01125X/1). Radar and aircraft datasets were made available by the British Atmospheric Data Centre (BADC). We would like to acknowledge the support from FAAM and Direct Flight in obtaining the aircraft dataset. ECMWF interim reanalysis archive data were used for the brief presentation of the synoptic condition of the present case (http://data.ecmwf.int/data/). NIMROD rain rate data were obtained from U.K. CEDA (http://catalogue.ceda. ac.uk/). Finally, Mr. Keppas was funded by the University of Manchester.

\section{REFERENCES}

Andrić, J., M. R. Kumjian, D. S. Zrnić, J. M. Straka, and V. M. Melnikov, 2013: Polarimetric signatures above the melting layer in winter storms: An observational and modeling study. J. Appl. Meteor. Climatol., 52, 682-700, https:// doi.org/10.1175/JAMC-D-12-028.1.

Bader, M. J., S. A. Clough, and G. P. Cox, 1987: Aircraft and dual polarization radar observations of hydrometeors in light stratiform precipitation. Quart. J. Roy. Meteor. Soc., 113, 491515, https://doi.org/10.1002/qj.49711347605.

Bailey, M. P., and J. Hallett, 2009: A comprehensive habit diagram for atmospheric ice crystals: Confirmation from the laboratory, AIRS II, and other field studies. J. Atmos. Sci., 66, 28882899, https://doi.org/10.1175/2009JAS2883.1.

Boodoo, S., D. Hudak, N. Donaldson, and M. Leduc, 2010: Application of dual-polarization radar melting-layer detection algorithm. J. Appl. Meteor. Climatol., 49, 1779-1793, https:// doi.org/10.1175/2010JAMC2421.1.

Brandes, E. A., and K. Ikeda, 2004: Freezing-level estimation with polarimetric radar. J. Appl. Meteor., 43, 1541-1553, https:// doi.org/10.1175/JAM2155.1.

Browning, K. A., 1971: Structure of the atmosphere in the vicinity of large-amplitude Kelvin-Helmholtz billows. Quart. J. Roy. Meteor. Soc., 97, 283-299, https://oi.org/10.1002/qj.49709741304.

_ 1986: Conceptual models of precipitation systems. Wea. Forecasting, 1, 23-41, https://doi.org/10.1175/1520-0434(1986)001<0023: CMOPS $>2.0 . \mathrm{CO} ; 2$.

_ 2004: The sting at the end of the tail: Damaging winds associated with extratropical cyclones. Quart. J. Roy. Meteor. Soc., 130, 375-399, https://doi.org/10.1256/qj.02.143.

- , and R. Wexler, 1968: The determination of kinematic properties of a wind field using Doppler radar. 
J. Appl. Meteor., 7, 105-113, https://doi.org/10.1175/15200450(1968)007<0105:TDOKPO > 2.0.CO;2.

— , G. W. Bryant, J. R. Starr, and D. N. Axford, 1973: Air motion within Kelvin-Helmholtz billows determined from simultaneous Doppler radar and aircraft measurements. Quart. J. Roy. Meteor. Soc., 99, 608-618, https://doi.org/10.1002/qj.49709942203.

Chapman, D., and K. A. Browning, 1998: Use of wind-shear displays for Doppler radar data. Bull. Amer. Meteor. Soc., 79, 2685-2692, https:// doi.org/10.1175/1520-0477(1998)079<2685:UOWSDF>2.0.CO;2.

Chen, S., and W. R. Cotton, 1988: The sensitivity of a simulated extratropical mesoscale convective system to longwave radiation and ice-phase microphysics. J. Atmos. Sci., 45, 3897-3910, https:// doi.org/10.1175/1520-0469(1988)045<3897:TSOASE>2.0.CO;2.

Choularton, T. W., J. Latham, and B. J. Mason, 1978: A possible mechanism of ice splinter production during riming. Nature, 274, 791-792, https://doi.org/10.1038/274791a0.

— D. J. Griggs, B. Y. Humood, and J. Latham, 1980: Laboratory studies of riming, and its relation to ice splinter production. Quart. J. Roy. Meteor. Soc., 106, 367-374, https://doi.org/ 10.1002/qj.49710644809.

Crawford, I., and Coauthors, 2012: Ice formation and development in aged, wintertime cumulus over the UK: Observations and modelling. Atmos. Chem. Phys., 12, 4963-4985, https://doi.org/ 10.5194/acp-12-4963-2012.

Crosier, J., and Coauthors, 2011: Observations of ice multiplication in a weakly convective cell embedded in supercooled midlevel stratus. Atmos. Chem. Phys., 11, 257-273, https://doi.org/ 10.5194/acp-11-257-2011.

—_, and Coauthors, 2014: Microphysical properties of cold frontal rainbands. Quart. J. Roy. Meteor. Soc., 140, 1257-1268, https:// doi.org/10.1002/qj.2206.

Dearden, C., G. Vaughan, T. Tsai, and J.-P. Chen, 2016: Exploring the diabatic role of ice microphysical processes in two North Atlantic summer cyclones. Mon. Wea. Rev., 144, 1249-1272, https://doi.org/10.1175/MWR-D-15-0253.1.

Douglas, R. H., K. L. S. Gunn, and J. S. Marshall, 1957: Pattern in the vertical of snow generation. J. Meteor., 14, 95-114, https:// doi.org/10.1175/1520-0469(1957)014<0095:PITVOS>2.0.CO;2.

Doviak, R. J., D. S. Zrnić, and D. S. Sirmans, 1979: Doppler weather radar. Proc. IEEE, 67, 1522-1553, https://doi.org/ 10.1109/PROC.1979.11511.

Eckhardt, S., A. Stohl, H. Wernli, P. James, C. Forster, and N. Spichtinger, 2004: A 15-year climatology of warm conveyor belts. J. Climate, 17, 218-237, https://doi.org/10.1175/15200442(2004)017<0218:AYCOWC>2.0.CO;2.

Ellis, S., and Coauthors, 2012: Towards the detection of aircraft icing conditions using operational dual-polarimetric radar. Seventh European Radar Conf. on Radar in Meteorology and Hydrology, Toulouse, France, Meteo-France, 6 pp., http://www.meteo.fr/cic/meetings/2012/ERAD/extended_abs/ ATM_352_ext_abs.pdf.

Fabry, F., and I. Zawadzki, 1995: Long-term radar observations of the melting layer of precipitation and their interpretation. J. Atmos. Sci., 52, 838-851, https://doi.org/10.1175/15200469(1995)052<0838:LTROOT>2.0.CO;2.

Field, P. R., A. J. Heymsfield, and A. Bansemer, 2006: Shattering and particle interarrival times measured by optical array probes in ice clouds. J. Atmos. Oceanic Technol., 23, 13571371, https://doi.org/10.1175/JTECH1922.1.

Findeisen, W., 1940: The formation of the $0^{\circ} \mathrm{C}$ isothermal layer and fractocumulus under nimbostratus. Meteor. Z., 57, 49-54.

Forbes, R. M., and P. A. Clark, 2003: Sensitivity of extratropical cyclone mesoscale structure to the parametrization of ice microphysical processes. Quart. J. Roy. Meteor. Soc., 129, 1123-1148, https://doi.org/10.1256/qj.01.171.

Fukao, S., and K. Hamazu, 2013: Radar for Meteorological and Atmospheric Observations. Springer Japan, 537 pp.

Giangrande, S. E., and A. V. Ryzhkov, 2005: Calibration of dualpolarization radar in the presence of partial beam blockage. J. Atmos. Oceanic Technol., 22, 1156-1166, https://doi.org/ 10.1175/JTECH1766.1.

— J. M. Krause, and A. V. Ryzhkov, 2008: Automatic designation of the melting layer with a polarimetric prototype of the WSR-88D radar. J. Appl. Meteor. Climatol., 47, 1354-1364, https://doi.org/10.1175/2007JAMC1634.1.

Godard, S., 1970: Propagation of centimeter and millimeter wavelengths through precipitation. IEEE Trans. Antennas Propag., 18, 530-534, https://doi.org/10.1109/TAP.1970.1139727.

Goddard, J. W. F., J. D. Eastment, and J. Tan, 1994: Self-consistent measurements of differential phase and differential reflectivity in rain. Proc. 1994 Int. Geoscience and Remote Sensing Symp., Pasadena, CA, IEEE, 369-371, https://doi.org/ 10.1109/IGARSS.1994.399128

Griffin, E. M., T. J. Schuur, A. V. Ryzhkov, H. D. Reeves, and J. C. Picca, 2014: A polarimetric and microphysical investigation of the Northeast blizzard of 8-9 February 2013. Wea. Forecasting, 29, 1271-1294, https://doi.org/10.1175/WAF-D-14-00056.1.

Hall, M. P. M., J. W. F. Goddard, and S. M. Cherry, 1984: Identification of hydrometeors and other targets by dualpolarization radar. Radio Sci., 19, 132-140.

Hallett, J., and S. C. Mossop, 1974: Production of secondary ice particles during the riming process. Nature, 249, 26-28, https:// doi.org/10.1038/249026a0.

Harrold, T. W., 1973: Mechanisms influencing the distribution of precipitation within baroclinic disturbances. Quart. J. Roy. Meteor. Soc., 99, 232-251, https://doi.org/10.1002/qj.49709942003.

Herzegh, P. H., and P. V. Hobbs, 1980: The mesoscale and microscale structure and organization of clouds and precipitation in midlatitude cyclones. II: Warm-frontal clouds. J. Atmos. Sci., 37, 597-611, https://doi.org/10.1175/15200469(1980)037<0597:TMAMSA > 2.0.CO;2.

— and organization of clouds and precipitation in midlatitude cyclones. IV: Vertical air motions and microphysical structures of prefrontal surge clouds and cold-frontal clouds. J. Atmos. Sci., 38, 1771-1784, https://doi.org/10.1175/15200469(1981)038<1771:TMAMSA > 2.0.CO;2.

—, and A. R. Jameson, 1992: Observing precipitation through dual-polarization radar measurements. Bull. Amer. Meteor. Soc., 73, 1365-1376, https://doi.org/10.1175/15200477(1992)073<1365:OPTDPR > 2.0.CO;2.

Heymsfield, A. J., 1972: Ice crystal terminal velocities. J. Atmos. Sci., 29, 1348-1357, https://doi.org/10.1175/15200469(1972)029<1348:ICTV>2.0.CO;2.

- and J. Iaquinta, 2000: Cirrus crystal terminal velocities. J. Atmos. Sci., 57, 916-938, https://doi.org/10.1175/15200469(2000)057<0916:CCTV>2.0.CO;2.

—_, G.-J. van Zadelhoff, D. P. Donovan, F. Fabry, R. J. Hogan, and A. J. Illingworth, 2007: Refinements to ice particle mass dimensional and terminal velocity relationships for ice clouds. Part II: Evaluation and parameterizations of ensemble ice particle sedimentation velocities. J. Atmos. Sci., 64, 1068-1088, https://doi.org/ 10.1175/JAS3900.1.

Hobbs, P. V., and R. J. Farber, 1972: Fragmentation of ice particles in clouds. J. Rech. Atmos., 6, 245-258. 
—_ and J. D. Locatelli, 1978: Rainbands, precipitation cores and generating cells in a cyclonic storm. J. Atmos. Sci., 35, 230-241, https:// doi.org/10.1175/1520-0469(1978)035<0230:RPCAGC>2.0.CO;2.

Hogan, R. J., P. R. Field, A. J. Illingworth, R. J. Cotton, and T. W. Choularton, 2002: Properties of embedded convection in warm-frontal mixed-phase cloud from aircraft and polarimetric radar. Quart. J. Roy. Meteor. Soc., 128, 451-476, https:// doi.org/10.1256/003590002321042054.

Houze, R. A., Jr., 2014: Cloud Dynamics. International Geophysics Series, Vol. 104, Academic Press, 432 pp.

_ J. D. Locatelli, and P. V. Hobbs, 1976: Dynamics and cloud microphysics of the rainbands in an occluded frontal system. J. Atmos. Sci., 33, 1921-1936, https://doi.org/10.1175/15200469(1976)033<1921:DACMOT>2.0.CO;2.

Hubbert, J., V. N. Bringi, L. D. Carey, and S. Bolen, 1998: CSUCHILL polarimetric radar measurements from a severe hail storm in eastern Colorado. J. Appl. Meteor., 37, 749-775, https:// doi.org/10.1175/1520-0450(1998)037<0749:CCPRMF>2.0.CO;2.

Illingworth, A. J., J. W. F. Goddard, and S. M. Cherry, 1987: Polarization radar studies of precipitation development in convective storms. Quart. J. Roy. Meteor. Soc., 113, 469-489, https://doi.org/10.1002/qj.49711347604.

Jayaweera, K. O. L. F., and R. E. Cottis, 1969: Fall velocities of plate-like and columnar ice crystals. Quart. J. Roy. Meteor. Soc., 95, 703-709, https://doi.org/10.1002/qj.49709540604.

Jiang, H., W. R. Cotton, J. O. Pinto, J. A. Curry, and M. J. Weissbluth, 2000: Cloud resolving simulations of mixed-phase Arctic stratus observed during BASE: Sensitivity to concentration of ice crystals and large-scale heat and moisture advection. J. Atmos. Sci., 57, 2105-2117, https://doi.org/10.1175/ 1520-0469(2000)057<2105:CRSOMP > 2.0.CO;2.

Kajikawa, M., 1972: Measurement of falling velocity of individual snow crystals. J. Meteor. Soc. Japan, 50, 577-584, https:// doi.org/10.2151/jmsj1965.50.6_577.

Keeler, J. M., B. F. Jewett, R. M. Rauber, G. M. McFarquhar, R. M. Rasmussen, L. Xue, C. Liu, and G. Thompson, 2016a: Dynamics of cloud-top generating cells in winter cyclones. Part I: Idealized simulations in the context of field observations. J. Atmos. Sci., 73, 1507-1527, https://doi.org/10.1175/JAS-D-15-0126.1.

of cloud-top generating cells in winter cyclones. Part II: Radiative and instability forcing. J. Atmos. Sci., 73, 1529-1553, https://doi.org/10.1175/JAS-D-15-0127.1.

—, R. M. Rauber, B. F. Jewett, G. M. McFarquhar, R. M. Rasmussen, L. Xue, C. Liu, and G. Thompson, 2017: Dynamics of cloud-top generating cells in winter cyclones. Part III: Shear and convective organization. J. Atmos. Sci., 74, 2879-2897, https://doi.org/10.1175/JAS-D-16-0314.1.

Kennedy, P. C., and S. A. Rutledge, 2011: S-band dual-polarization radar observations of winter storms. J. Appl. Meteor. Climatol., 50, 844-858, https://doi.org/10.1175/2010JAMC2558.1.

Keppas, S. Ch., J. Crosier, T. W. Choularton, and K. N. Bower, 2017: Ice lollies: An ice particle generated in supercooled conveyor belts. Geophys. Res. Lett., 44, 5222-5230, https:// doi.org/10.1002/2017GL073441.

Keyser, D., 1986: Atmospheric fronts: An observational perspective. Mesoscale Meteorology and Forecasting, P. S. Ray, Ed., Amer. Meteor. Soc., 216-258, https://doi.org/10.1007/978-1-935704-20-1_10.

Knight, C. A., 1979: Observations of the morphology of melting snow. J. Atmos. Sci., 36, 1123-1130, https://doi.org/10.1175/ 1520-0469(1979)036<1123:OOTMOM >2.0.CO;2.

Knollenberg, R. G., 1970: The optical array: An alternative to scattering or extinction for airborne particle size determination.
J. Appl. Meteor., 9, 86-103, https://doi.org/10.1175/1520-0450 (1970)009<0086:TOAAAT>2.0.CO;2.

Kobayashi, T., 1961: The growth of snow crystals at low supersaturations. Philos. Mag., 6, 1363-1370, https://doi.org/10.1080/ 14786436108241231.

Kollias, P., E. E. Clothiaux, M. A. Miller, B. A. Albrecht, G. L. Stephens, and T. P. Ackerman, 2007: Millimeter-wavelength radars: New frontier in atmospheric cloud and precipitation research. Bull. Amer. Meteor. Soc., 88, 1608-1624, https:// doi.org/10.1175/BAMS-88-10-1608.

Koop, T., B. Luo, A. Tsias, and T. Peter, 2000: Water activity as the determinant for homogeneous ice nucleation in aqueous solutions. Nature, 406, 611-614, https://doi.org/10.1038/35020537.

Kumjian, M. R., 2013: Principles and applications of dualpolarization weather radar. Part I: Description of the polarimetric radar variables. J. Oper. Meteor., 1, 226-242, https:// doi.org/10.15191/nwajom.2013.0119.

— , and A. V. Ryzhkov, 2008: Polarimetric signatures in supercell thunderstorms. J. Appl. Meteor. Climatol., 47, 1940-1961, https://doi.org/10.1175/2007JAMC1874.1.

— S. A. Rutledge, R. M. Rasmussen, P. C. Kennedy, and M. Dixon, 2014: High-resolution polarimetric radar observations of snow-generating cells. J. Appl. Meteor. Climatol., 53, 1636-1658, https://doi.org/10.1175/JAMC-D-13-0312.1.

Lance, S., C. A. Brock, D. Rogers, and J. A. Gordon, 2010: Water droplet calibration of the Cloud Droplet Probe (CDP) and inflight performance in liquid, ice and mixed-phase clouds during ARCPAC. Atmos. Meas. Tech., 3, 1683-1706, https:// doi.org/10.5194/amt-3-1683-2010.

Langleben, M. P., 1956: The plan pattern of snow echoes at the generating level. J. Meteor., 13, 554-560, https://doi.org/ 10.1175/1520-0469(1956)013<0554:TPPOSE > 2.0.CO;2.

Lavers, D. A., R. P. Allan, E. F. Wood, G. Villarini, D. J. Brayshaw, and A. J. Wade, 2011: Winter floods in Britain are connected to atmospheric rivers. Geophys. Res. Lett., 38, L23803, https:/ doi.org/10.1029/2011GL049783.

Lawson, R. P., D. O'Connor, P. Zmarzly, K. Weaver, B. Baker, Q. Mo, and H. Jonsson, 2006: The 2D-S (stereo) probe: Design and preliminary tests of a new airborne, high-speed, highresolution particle imaging probe. J. Atmos. Oceanic Technol., 23, 1462-1477, https://doi.org/10.1175/JTECH1927.1.

Lloyd, G., C. Dearden, T. W. Choularton, J. Crosier, and K. N. Bower, 2014: Observations of the origin and distribution of ice in cold, warm, and occluded frontal systems during the DIAMET campaign. Mon. Wea. Rev., 142, 4230-4255, https:// doi.org/10.1175/MWR-D-13-00396.1.

Magono, C., and C. W. Lee, 1966: Meteorological classification of natural snow crystals. J. Fac. Sci. Hokkaido Univ., Ser. 7, 2, 321-335.

Marshall, J. S., 1953: Precipitation trajectories and patterns. J. Meteor., 10, 25-29, https://doi.org/10.1175/1520-0469(1953)010<0025: PTAP $>2.0 . \mathrm{CO} ; 2$.

Matejka, T. J., R. A. Houze, and P. V. Hobbs, 1980: Microphysics and dynamics of clouds associated with mesoscale rainbands in extratropical cyclones. Quart. J. Roy. Meteor. Soc., 106, 29-56, https://doi.org/10.1002/qj.49710644704.

Mitchell, D. L., 1996: Use of mass- and area-dimensional power laws for determining precipitation particle terminal velocities. J. Atmos. Sci., 53, 1710-1723, https://doi.org/10.1175/15200469(1996)053<1710:UOMAAD>2.0.CO;2.

Moisseev, D. N., S. Lautaportti, J. Tyynela, and S. Lim, 2015: Dualpolarization radar signatures in snowstorms: Role of snowflake aggregation. J. Geophys. Res. Atmos., 120, 12 644-12 655, https://doi.org/10.1002/2015JD023884. 
Morrison, H., M. D. Shupe, J. O. Pinto, and J. A. Curry, 2005: Possible roles of ice nucleation mode and ice nuclei depletion in the extended lifetime of Arctic mixed-phase clouds. Geophys. Res. Lett., 32, L18801, https://doi.org/ 10.1029/2005GL023614.

Mossop, S. C., and J. Hallett, 1974: Ice crystal concentration in cumulus clouds: Influence of the drop spectrum. Science, 186, 632-634, https://doi.org/10.1126/science.186.4164.632.

Murakami, M., Y. Yamada, T. Matsuo, H. Mizuno, and K. Morikawa, 1992: Microphysical structures of warm-frontal clouds. J. Meteor. Soc. Japan, 70, 877-895, https://doi.org/ 10.2151/jmsj1965.70.5_877.

Murray, B. J., D. O'Sullivan, J. D. Atkinson, and M. E. Webb, 2012: Ice nucleation by particles immersed in supercooled cloud droplets. Chem. Soc. Rev., 41, 6519-6554, https://doi.org/ 10.1039/c2cs35200a.

Oraltay, R. G., and J. Hallett, 2005: The melting layer: A laboratory investigation of ice particle melt and evaporation near $0^{\circ}$ C. J. Appl. Meteor., 44, 206-220, https://doi.org/10.1175/ JAM2194.1.

Oue, M., M. R. Kumjian, Y. Lu, Z. Jiang, E. E. Clothiaux, J. Verlinde, and K. Aydin, 2015: X-band polarimetric and Ka-band Doppler spectral radar observations of a graupel-producing Arctic mixedphase cloud. J. Appl. Meteor. Climatol., 54, 1335-1351, https://doi. org/10.1175/JAMC-D-14-0315.1.

Pfahl, S., E. Madonna, M. Boettcher, H. Joos, and J. Wernli, 2014: Warm conveyor belts in the ERA-Interim dataset (19792010). Part II: Moisture origin and relevance for precipitation. J. Climate, 27, 27-40, https://doi.org/10.1175/ JCLI-D-13-00223.1.

Pinto, J. O., 1998: Autumnal mixed-phase cloudy boundary layers in the Arctic. J. Atmos. Sci., 55, 2016-2038, https://doi.org/ 10.1175/1520-0469(1998)055<2016:AMPCBL>2.0.CO;2.

Pitertsev, A., and F. Yanovsky, 2011: Polarimetric method for remote predicting a zone of icing-in-flight in clouds and precipitation. 2011 Microwaves, Radar and Remote Sensing Symp. (MRRS), Kiev, Ukraine, IEEE, https://doi.org/ 10.1109/MRRS.2011.6053640.

Plummer, D. M., G. M. McFarquhar, R. M. Rauber, B. F. Jewett, and D. C. Leon, 2014: Structure and statistical analysis of the microphysical properties of generating cells in the comma head region of continental winter cyclones. J. Atmos. Sci., 71, 4181-4203, https://doi.org/10.1175/JAS-D-14-0100.1.

,,,,---- and -2015 : Microphysical properties of convectively generated fall streaks within the stratiform comma head region of continental winter cyclones. J. Atmos. Sci., 72, 2465-2483, https://doi.org/10.1175/JAS-D-14-0354.1.

Protat, A., and C. R. Williams, 2011: The accuracy of radar estimates of ice terminal fall speed from vertically pointing Doppler radar measurements. J. Appl. Meteor. Climatol., 50, 2120-2138, https://doi.org/10.1175/JAMC-D-10-05031.1.

Pruppacher, H. R., and R. J. Schlamp, 1975: A wind tunnel investigation on ice multiplication by freezing of waterdrops falling at terminal velocity in air. J. Geophys. Res., 80, 380-386, https://doi.org/10.1029/JC080i003p00380.

Rauber, R. M., and Coauthors, 2015: The role of cloud-top generating cells and boundary layer circulations in the finescale radar structure of a winter cyclone over the Great Lakes. Mon. Wea. Rev., 143, 2291-2318, https://doi.org/10.1175/MWR-D14-00350.1.

Rosenow, A. A., D. M. Plummer, R. M. Rauber, G. M. McFarquhar, B. F. Jewett, and D. Leon, 2014: Vertical velocity and physical structure of generating cells and convection in the comma head region of continental winter cyclones. J. Atmos. Sci., 71, 1538-1558, https://doi.org/10.1175/JAS-D13-0249.1.

Ryzhkov, A. V., S. Giangrande, and D. Zrnić, 2002: Using multiparameter data to calibrate polarimetric weather radars in the presence of a partial beam blockage. 2002 Geoscience and Remote Sensing Symp., Toronto, Ontario, Canada, IEEE, https://doi.org/10.1109/IGARSS.2002.1026791.

— T. J. Schuur, D. W. Burgess, and D. S. Zrnić, 2005: Polarimetric tornado detection. J. Appl. Meteor., 44, 557-570, https://doi.org/10.1175/JAM2235.1.

— H. D. Reeves, T. J. Schuur, M. R. Kumjian, and D. S. Zrnić, 2011: Investigations of polarimetric radar signatures in winter storms and their relation to aircraft icing and freezing rain. 35th Conf. on Radar Meteorology, Pittsburgh, PA, Amer. Meteor. Soc., 197, https:/ams.confex.com/ams/35Radar/webprogram/ Paper191245.html.

Schrom, R. S., and M. R. Kumjian, 2016: Connecting microphysical processes in Colorado winter storms with vertical profiles of radar observations. J. Appl. Meteor. Climatol., 55, 1771-1787, https://doi.org/10.1175/JAMC-D-15-0338.1.

,-- , and Y. Lu, 2015: Polarimetric radar signatures of dendritic growth zones within Colorado winter storms. J. Appl. Meteor. Climatol., 54, 2365-2388, https://doi.org/10.1175/ JAMC-D-15-0004.1.

Seliga, T. A., and V. N. Bringi, 1976: Potential use of radar differential reflectivity measurements at orthogonal polarizations for measuring precipitation. J. Appl. Meteor., 15, 69-76, https://doi.org/ 10.1175/1520-0450(1976)015<0069:PUORDR > 2.0.CO;2.

Serke, D. J., M. K. Politovich, A. L. Reehorst, and A. Gaydos, 2008: The use of X-band radar to support the detection of in-flight icing hazards by the NASA Icing Remote Sensing System. Remote Sensing Applications for Aviation Weather Hazard Detection and Decision Support, W. Feltz and J. Murray, Eds., International Society for Optics and Photonics (SPIE Proceedings, Vol. 7088), 70880E, https://doi.org/10.1117/12.795290.

Smith, P. L., D. J. Musil, A. G. Detwiler, and R. Ramachandran, 1999: Observations of mixed-phase precipitation within a CaPE thunderstorm. J. Appl. Meteor., 38, 145-155, https://doi.org/ 10.1175/1520-0450(1999)038<0145:OOMPPW > 2.0.CO;2.

Stark, D., B. A. Colle, and S. E. Yuter, 2013: Observed microphysical evolution for two East Coast winter storms and the associated snow bands. Mon. Wea. Rev., 141, 2037-2057, https://doi.org/10.1175/MWR-D-12-00276.1.

Stewart, R. E., 1984: Deep $0^{\circ} \mathrm{C}$ isothermal layers within precipitation bands over southern Ontario. J. Geophys. Res., 89, 2567-2572, https://doi.org/10.1029/JD089iD02p02567.

, J. D. Marwitz, J. C. Pace, and R. E. Carbone, 1984: Characteristics through the melting layer of stratiform clouds. J. Atmos. Sci., 41, 3227-3237, https://doi.org/10.1175/15200469(1984)041<3227:CTTMLO>2.0.CO;2.

Stoelinga, M. T., and Coauthors, 2003: Improvement of microphysical parameterization through observational verification experiment. Bull. Amer. Meteor. Soc., 84, 1807-1826, https:// doi.org/10.1175/BAMS-84-12-1807.

Straka, J. M., D. S. Zrnić, and A. V. Ryzhkov, 2000: Bulk hydrometeor classification and quantification using polarimetric radar data: Synthesis of relations. J. Appl. Meteor., 39, 1341-1372, https://doi. org/10.1175/1520-0450(2000)039<1341:BHCAQU>2.0.CO;2.

Szeto, K. K., C. A. Lin, and R. E. Stewart, 1988: Mesoscale circulations forced by melting snow. Part I: Basic simulations and dynamics. J. Atmos. Sci., 45, 1629-1641, https://doi.org/ 10.1175/1520-0469(1988)045<1629:MCFBMS>2.0.CO;2. 
Szyrmer, W., and I. Zawadzki, 1999: Modeling of the melting layer. Part I: Dynamics and microphysics. J. Atmos. Sci., 56, 3573-3592, https:// doi.org/10.1175/1520-0469(1999)056<3573:MOTMLP>2.0.CO;2.

Vali, G., P. J. DeMott, O. Möhler, and T. F. Whale, 2015: Technical note: A proposal for ice nucleation terminology. Atmos. Chem. Phys., 15, 10 263-10 270, https://doi.org/10.5194/acp-1510263-2015.

Vardiman, L., 1978: The generation of secondary ice particles in clouds by crystal-crystal collision. J. Atmos. Sci., 35, 2168-2180, https://doi.org/10.1175/1520-0469(1978)035<2168: TGOSIP $>2.0 . \mathrm{CO} ; 2$.
Wakimoto, R. M., and B. L. Bosart, 2001: Airborne radar observations of a warm front during FASTEX. Mon. Wea. Rev., 129, 254-274, https:// doi.org/10.1175/1520-0493(2001)129<0254:AROOAW>2.0.CO;2.

Wexler, R., and D. Atlas, 1959: Precipitation generating cells. J. Meteor., 16, 327-332, https://doi.org/10.1175/1520-0469 (1959) $016<0327: \mathrm{PGC}>2.0 . \mathrm{CO} ; 2$.

Zrnić, D. S., N. Balakrishnan, C. L. Ziegler, V. N. Bringi, K. Aydin, and T. Matejka, 1993: Polarimetric signatures in the stratiform region of a mesoscale convective system. J. Appl. Meteor., 32, 678-693, https://doi.org/10.1175/ 1520-0450(1993)032<0678:PSITSR >2.0.CO;2. 